\title{
LADUE ELECTROMAGNETIC AND MAGNETIC AIRBORNE GEOPHYSICAL SURVEY DATA COMPILATION
}

Burns, L.E., Graham, G.R.C., Barefoot, J.D., Naibert, T.J., Fugro Airborne Surveys Corp., and Fugro GeoServices, Inc.

Geophysical Report 2019-20

2020

STATE OF ALASKA

DEPARTMENT OF NATURAL RESOURCES

DIVISION OF GEOLOGICAL \& GEOPHYSICAL SURVEYS
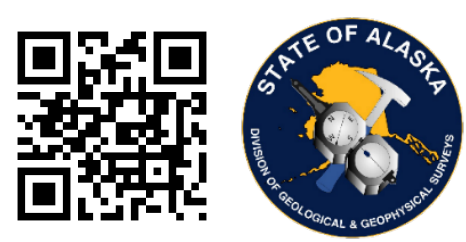
STATE OF ALASKA

Mike Dunleavy, Governor

\title{
DEPARTMENT OF NATURAL RESOURCES
}

Corri A. Feige, Commissioner

\section{DIVISION OF GEOLOGICAL \& GEOPHYSICAL SURVEYS}

Steve Masterman, State Geologist \& Director

Publications produced by the Division of Geological \& Geophysical Surveys are available to download from the DGGS website (dggs.alaska.gov). Publications on hard-copy or digital media can be examined or purchased in the Fairbanks office:

\author{
Alaska Division of Geological \& Geophysical Surveys (DGGS) \\ 3354 College Road | Fairbanks, Alaska 99709-3707 \\ Phone: 907.451.5010 | Fax 907.451.5050 \\ dggspubs@alaska.gov $\mid$ dggs.alaska.gov
}

DGGS publications are also available at:

Alaska State Library, Historical

Collections \& Talking BookCenter

395 Whittier Street

Juneau, Alaska 99801

Alaska Resource Library and

Information Services (ARLIS)

3150 C Street, Suite 100

Anchorage, Alaska 99503

\section{Suggested citation:}

Burns, L.E., Graham, G.R.C., Barefoot, J.D., Naibert, TJ., Fugro Airborne Surveys Corp., and Fugro

GeoServices, Inc., 2020, Ladue electromagnetic and magnetic airborne geophysical survey data compilation: Alaska Division of Geological \& Geophysical Surveys Geophysical Report 2019-20. http://doi.org/10.14509/30261
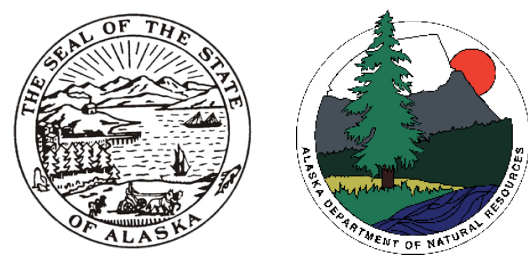


\section{LADUE ELECTROMAGNETIC AND MAGNETIC AIRBORNE GEOPHYSICAL SURVEY DATA COMPILATION}

Burns, L.E. ', Graham, G.R.C. ', Barefoot, J.D. , , Naibert, T.J. ${ }^{1}$ Fugro Airborne Surveys Corp., and

Fugro GeoServices, Inc.

\section{ABSTRACT}

The Ladue electromagnetic and magnetic airborne geophysical survey is located in eastern Alaska in the Fortymile mining district, about 325 kilometers southeast of Fairbanks. Frequency domain electromagnetic and magnetic data were collected with the DIGHEM ${ }^{\mathrm{v}}$ system in August 2010. A total of 5,471.1 line kilometers were collected covering 1,928.9 square kilometers. Line spacing was 400 meters (m). Data were collected 30 $\mathrm{m}$ above the ground surface from a helicopter towed sensor platform ("bird") on a $30 \mathrm{~m}$ long line.

\section{PURPOSE}

This airborne geophysical survey is part of a program to acquire data on Alaska's most promising mineral belts and districts. The information acquired is aimed at catalyzing new private-sector exploration, discovery, and ultimate development and production. The purpose of the survey was to map the magnetic and conductive properties of the survey area. The Fortymile mining district contains the oldest placer gold camp in Alaska, but mineral exploration has been impeded by thick vegetation. Prospects in the area include Pika, Taurus, and Fishhook. Other gold and base-metal anomalies, altered zones, favorable lithologies, and structural zones are known to exist throughout the survey area.

\section{SURVEY OVERVIEW DESCRIPTION}

This document provides an overview of the survey and includes text and figures of select primary and derivative products of this survey. A table of digital data packages available for download is provided to assist users in data selection. For reference, a catalog of the available maps is presented in reduced resolution. Please consult the metadata, project report, and digital data packages for more information and data.

\section{ACKNOWLEDGMENTS}

Funding was provided by the Alaska State Legislature as part of the DGGS Airborne Geophysical/Geological Mineral Inventory (AGGMI) program.

\footnotetext{
${ }^{1}$ Alaska Division of Geological \& Geophysical Surveys, 3354 College Road, Fairbanks, Alaska 99709-3707
} 


\begin{tabular}{|c|c|c|}
\hline Data Type & Provider & Description \\
\hline ascii_data & contractor & ASCII format line data, other ASCII data \\
\hline databases_geosoft & contractor & $\begin{array}{l}\text { Geosoft format database of final line data, other } \\
\text { Geosoft format databases }\end{array}$ \\
\hline documents & contractor and DGGS & $\begin{array}{l}\text { Project and field reports, survey background } \\
\text { information, gridded data explanations, other } \\
\text { documentation }\end{array}$ \\
\hline grids_ermapper & contractor and DGGS & $\begin{array}{l}\text { Geographically registered gridded data, ER Mapper } \\
\text { ERS format }\end{array}$ \\
\hline grids_geosoft & contractor and DGGS & $\begin{array}{l}\text { Geosoft-format grids, these grids can be viewed in } \\
\text { ESRI ArcMap using a free plugin from Geosoft or the } \\
\text { free viewer available from Geosoft }\end{array}$ \\
\hline images_registered & DGGS & GeoTiff format images of all gridded data \\
\hline $\mathrm{kmz}$ & DGGS & $\begin{array}{l}\text { keyhole markup language }(\mathrm{kml}) \mathrm{kmz} \text { archive files of } \\
\text { project data. Viewable in Google Earth and other } \\
\text { compatible programs }\end{array}$ \\
\hline maps_pdf_format & contractor and DGGS & Printable maps in pdf format \\
\hline maps_prn_format & contractor & $\begin{array}{l}\text { Printable maps in HPGL/2 printer file format with } \\
\text { extension .prn }\end{array}$ \\
\hline profiles_stacked & contractor & $\begin{array}{l}\text { Distance-based profiles of the digitally recorded } \\
\text { geophysical data are generated and plotted at an } \\
\text { appropriate scale. The profiles display } \\
\text { electromagnetic anomalies with their respective } \\
\text { interpretive symbols. Printable in pdf format }\end{array}$ \\
\hline vector_data & contractor and DGGS & $\begin{array}{l}\text { Line path, data contours, and survey boundary in } \\
\text { ESRI shapefile (SHP) format, ESRI Geodatabase } \\
\text { format, and/or AutoCAD dxf format }\end{array}$ \\
\hline video_flightpath & contractor & Survey flight path downward facing video \\
\hline
\end{tabular}




\section{REFERENCES}

Akima, H., 1970, A new method of interpolation and smooth curve fitting based on local procedures: Journal of the Association of Computing Machinery, v. 17, n. 4, p. 589-602.

Burns, L.E., Fugro Airborne Surveys Corp., and Fugro GeoServices, Inc., 2011, Ladue survey area: Magnetic and electromagnetic line, grid, and vector data and Maps, Fortymile mining district, Tanacross Quadrangle, eastern Alaska: Alaska Division of Geological \& Geophysical Surveys Geophysical Report 2011-1, 26 sheets, scale 1:63,360, 1 DVD. http://doi.org/10.14509/22562 


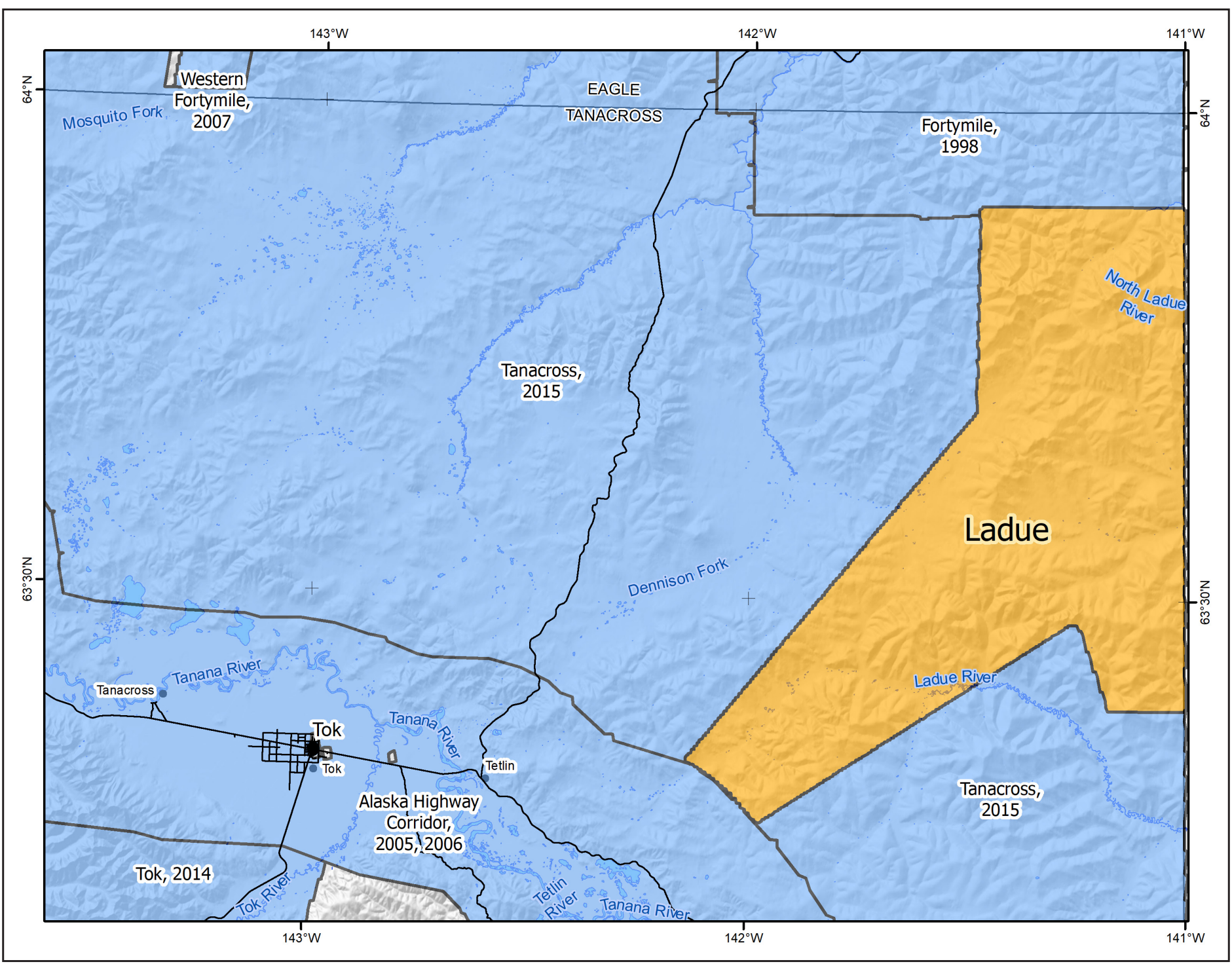

Figure 1. Ladue electromagnetic and magnetic airborne geophysical survey location shown in western Alaska (inset). Ladue survey area shown with adjacent DGGS geophysical surveys, landmarks, relevant 1:250,000-scale quadrangle boundaries, mountain ranges, rivers, and elevation hillshade. 


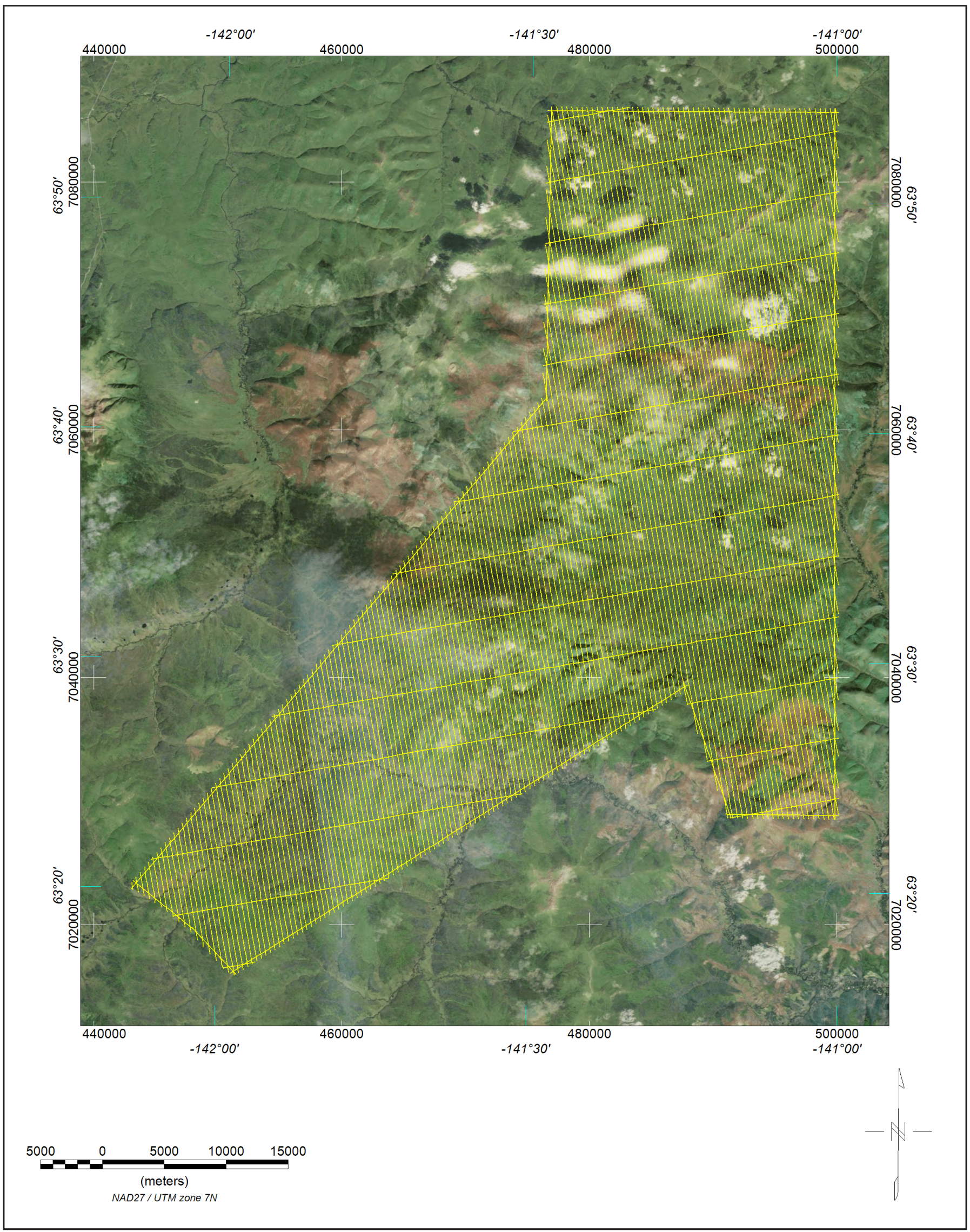

Figure 2. Flight path with orthometric image. 


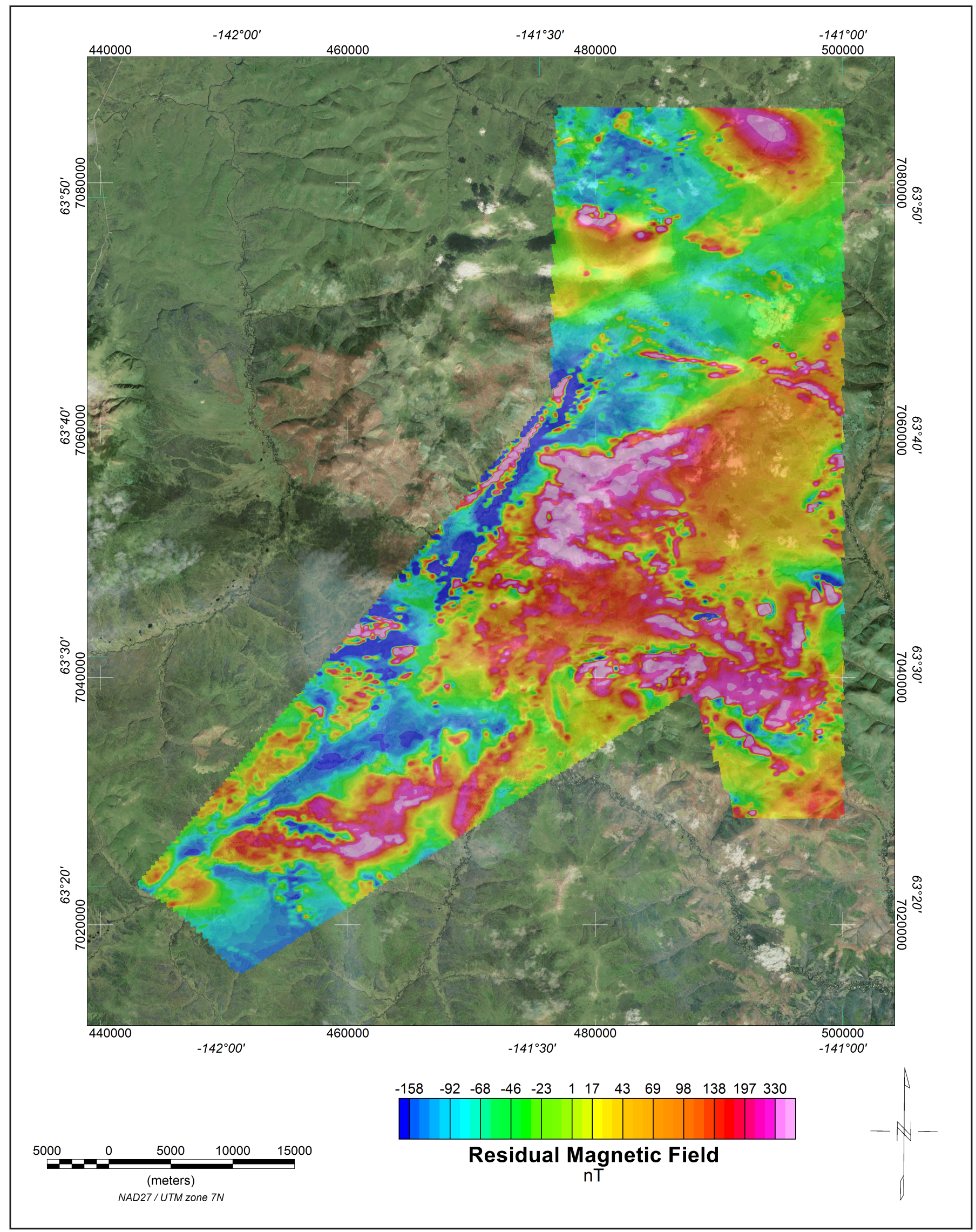

Figure 3. Residual Magnetic Field Grid with orthometric image. The magnetic total field data were processed using digitally recorded data from a Fugro D1344 magnetometer with a Scintrex CS3 cesium sensor. Data were collected at a sampling interval of 0.1 seconds. The magnetic data were (1) corrected for diurnal variations by subtracting the digitally recorded base station magnetic data, (2) IGRF corrected (IGRF model 2010, updated for date of flight and altimeter variations), (3) leveled to the tie line data, and (4) interpolated onto a regular $80 \mathrm{~m}$ grid using a modified Akima (1970) technique. 


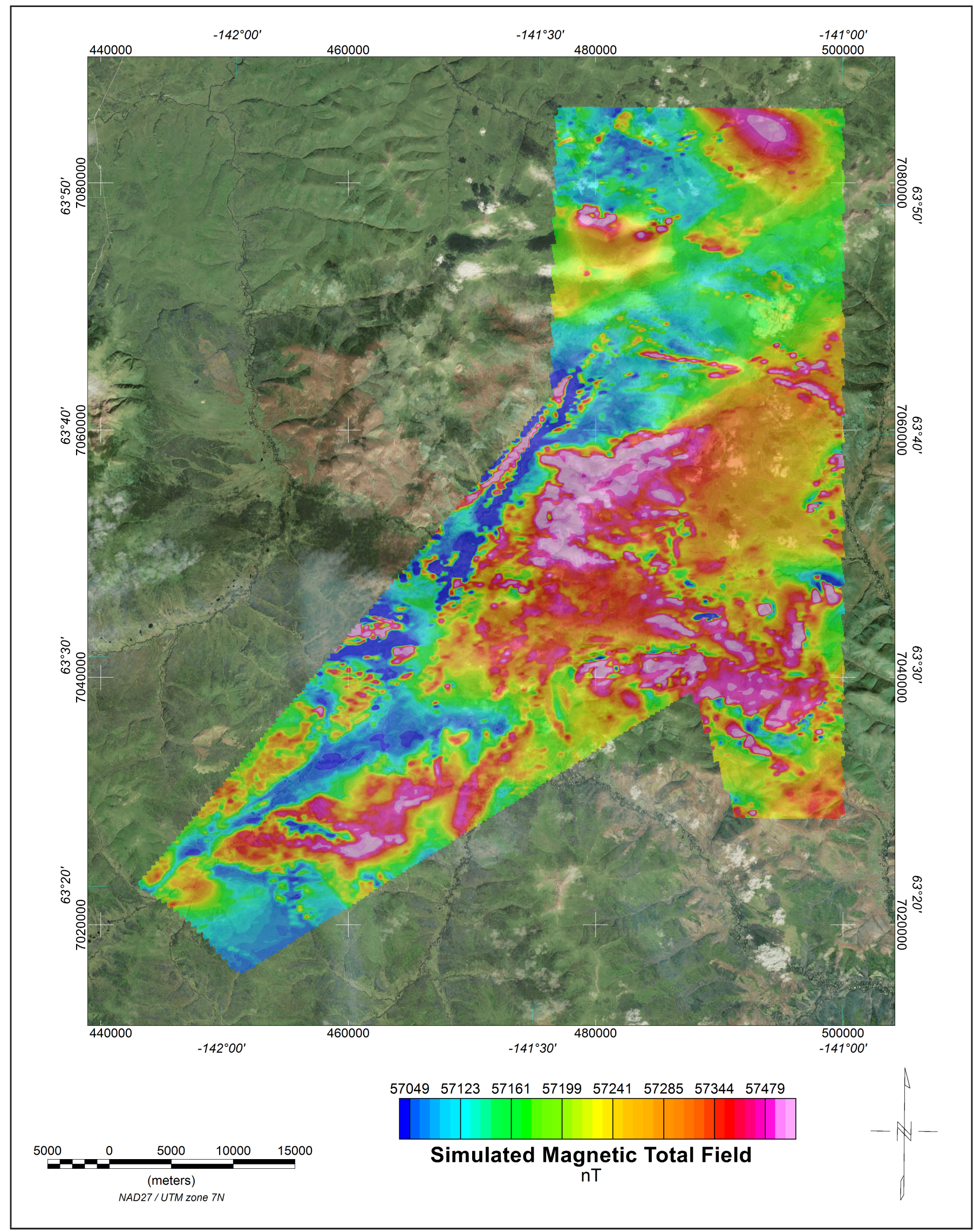

Figure 4. Simulated Magnetic Total Field Grid with orthometric image. The magnetic total field data were processed using digitally recorded data from a Fugro D1344 magnetometer with a Scintrex CS3 cesium sensor. Data were collected at a sampling interval of 0.1 seconds. The magnetic data were (1) corrected for diurnal variations by subtracting the digitally recorded base station magnetic data, (2) IGRF corrected (IGRF model 2010, updated for date of flight and altimeter variations), (3) leveled to the tie line data, (4) a constant value of approximately 57,000 nT was added to all data, and (5) interpolated onto a regular $80 \mathrm{~m}$ grid using a modified Akima (1970) technique. 


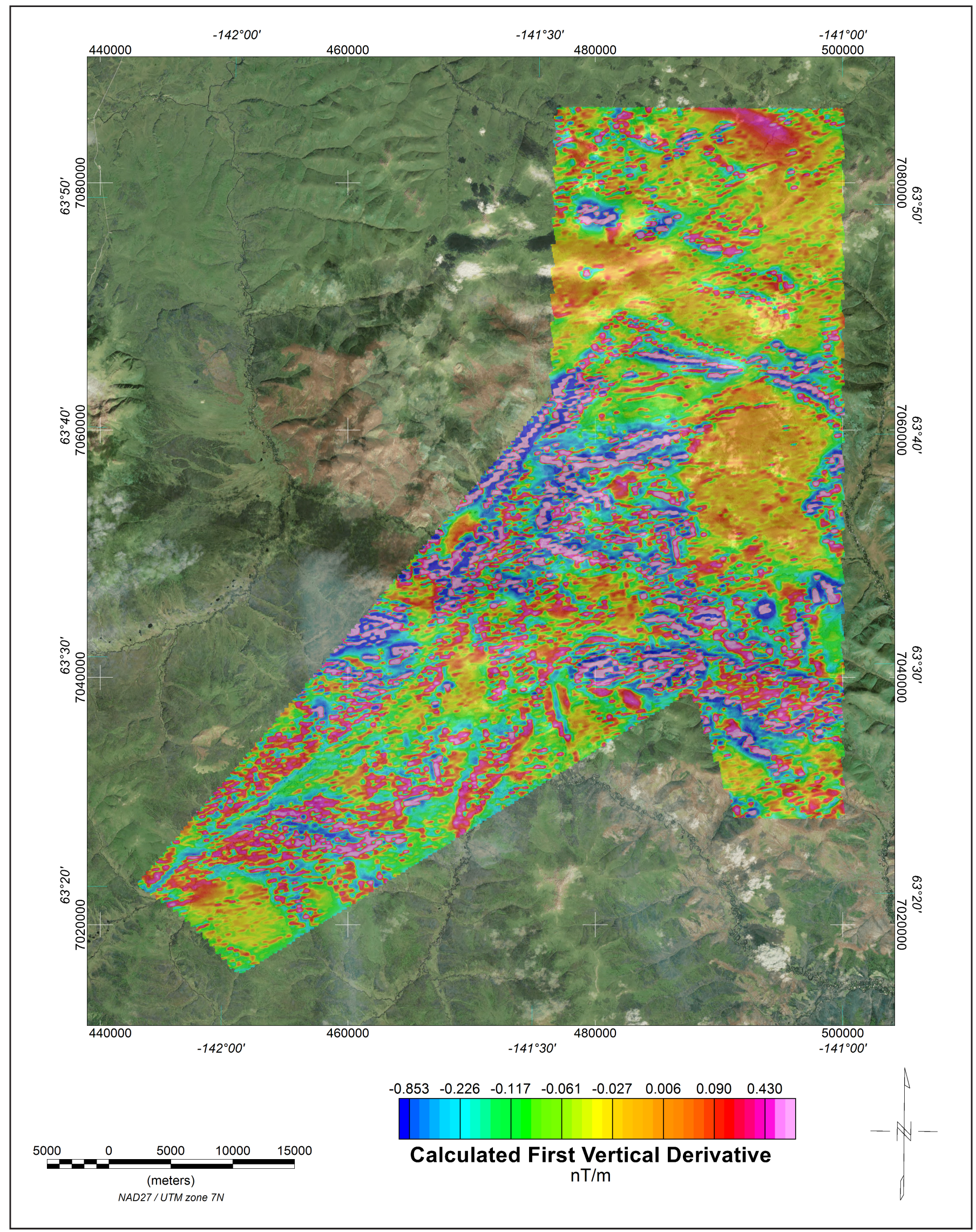

Figure 5. Calculated first vertical derivative grid with orthometric image. The first vertical derivative grid was calculated from the diurnally-corrected, IGRF-corrected total magnetic field grid using a FFT base frequency domain filtering algorithm. The resulting first vertical derivative grid provides better definition and resolution of near- surface magnetic units and helps to identify weak magnetic features that may not be evident on the total field data. 


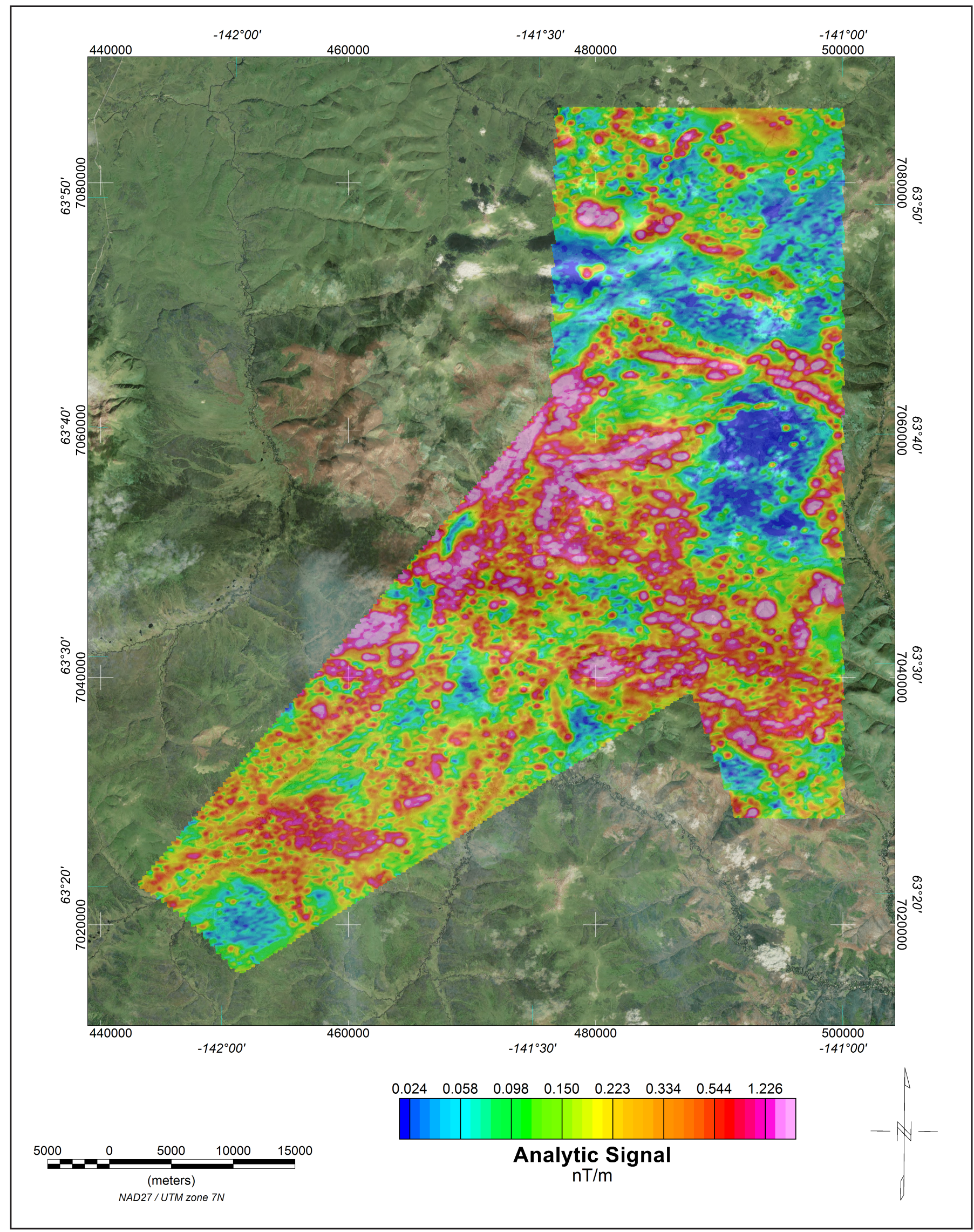

Figure 6. Analytic signal grid with orthometric image. Analytic signal is the total amplitude of all directions of magnetic gradient calculated from the sum of the squares of the three orthogonal gradients. Mapped highs in the calculated analytic signal of magnetic parameter locate the anomalous source body edges and corners (such as contacts, fault/shear zones, etc.). Analytic signal maxima are located directly over faults and contacts, regardless of structural dip, and independent of the direction of the induced and/or remanent magnetizations. 


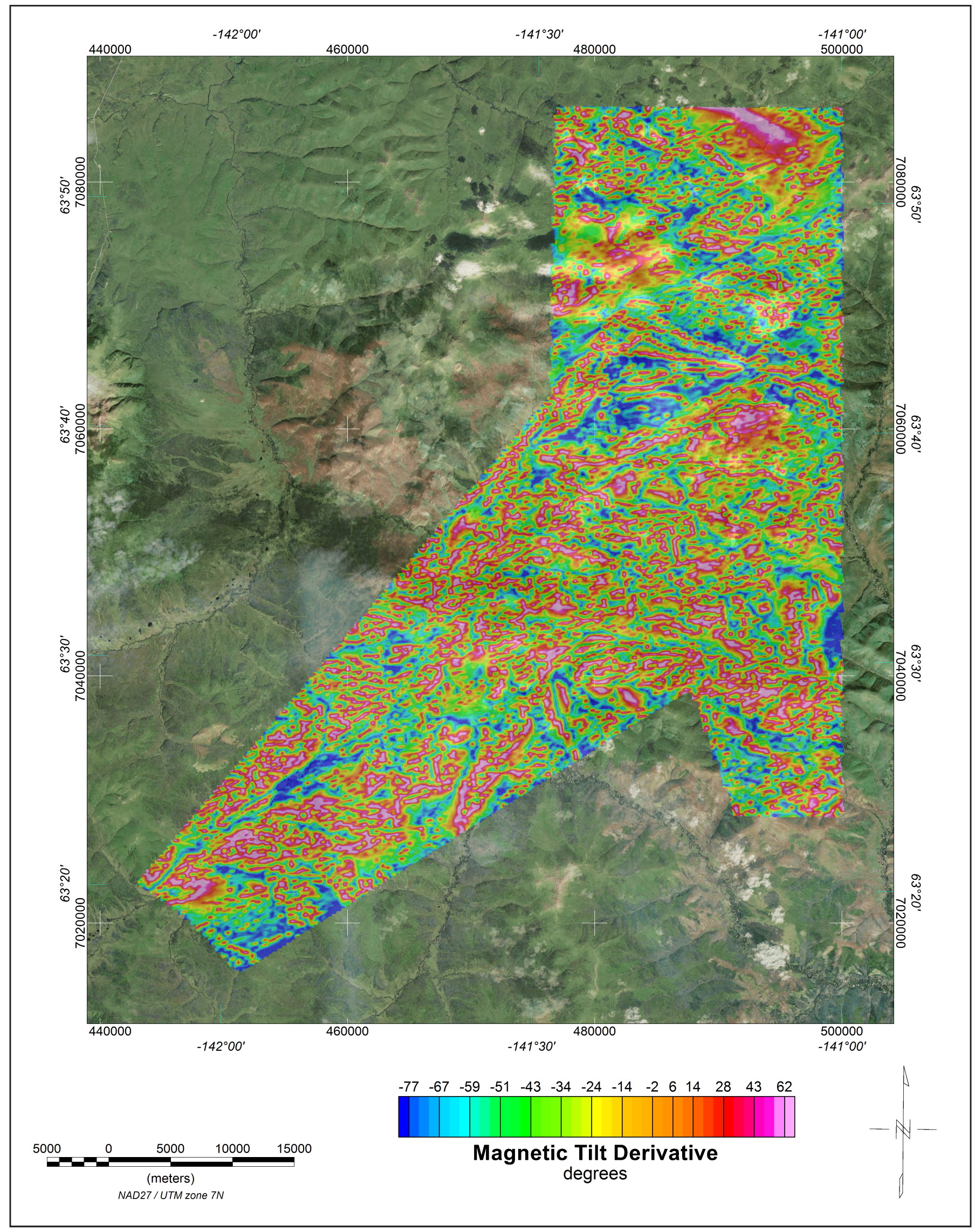

Figure 7. Magnetic tilt derivative grid with orthometric image. The tilt derivative is the angle between the horizontal gradient and the total gradient, which is useful for identifying the depth and type of source. The tilt angle is positive over the source, crosses through zero at, or near, the edge of a vertical sided source, and is negative outside the source region. It has the added advantage of responding equally well to shallow and deep sources and is able to resolve deeper sources that may be masked by larger responses from shallower sources. 


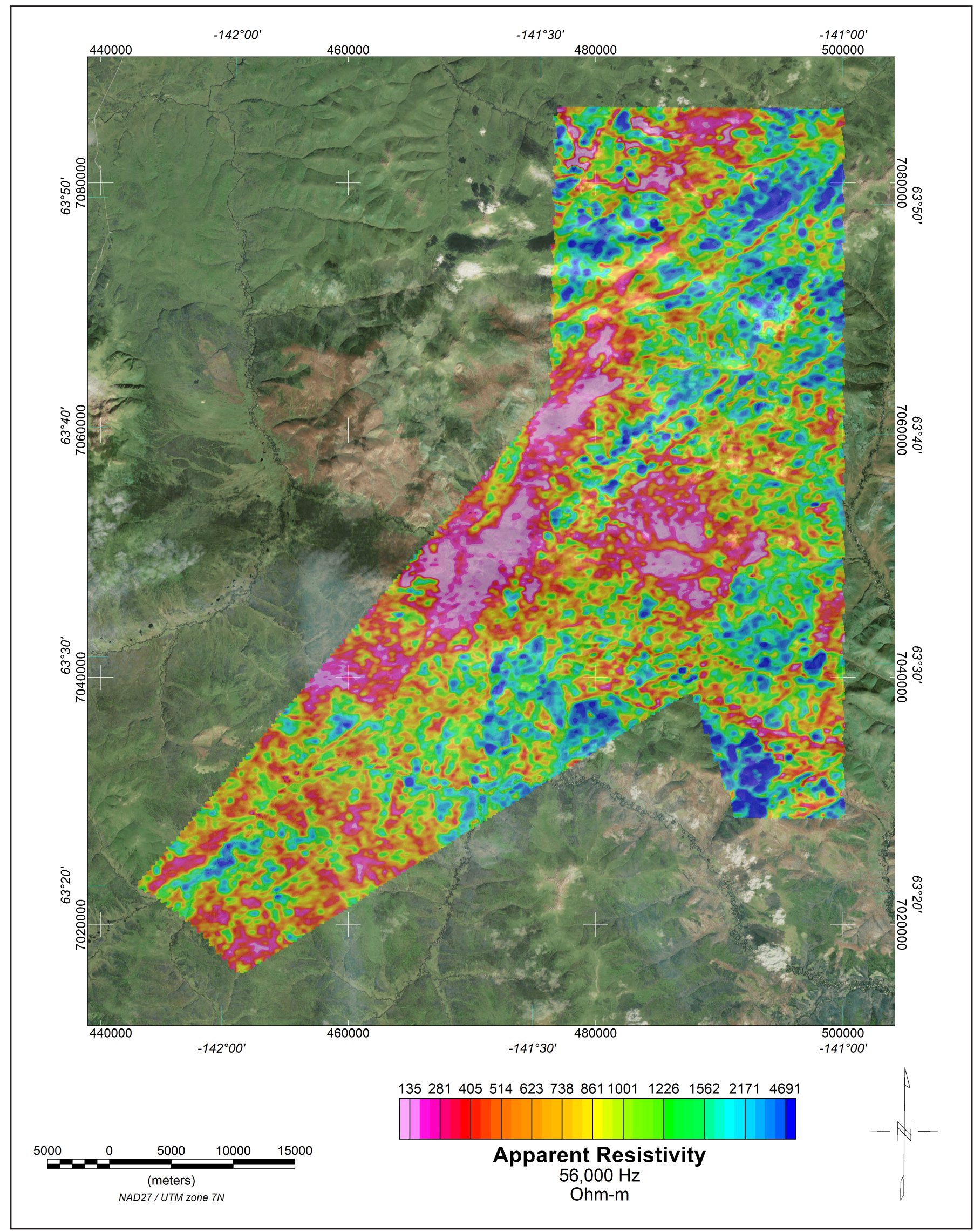

Figure 8. 56,000 Hz coplanar apparent resistivity grid with orthometric image. The DIGHEM ${ }^{\vee} E M$ system measured inphase and quadrature components at five frequencies. Two vertical coaxial coil-pairs operated at 1,000 and $5,500 \mathrm{~Hz}$ while three horizontal coplanar coil-pairs operated at $900,7,200$, and $56,000 \mathrm{~Hz}$. EM data were sampled at 0.1 second intervals. The EM system responds to bedrock conductors, conductive overburden, and cultural sources. Apparent resistivity is generated from the inphase and quadrature component of the coplanar $56,000 \mathrm{~Hz}$ using the pseudo-layer half space model. The data were interpolated onto a regular $80 \mathrm{~m}$ grid using a modified Akima (1970) technique. 


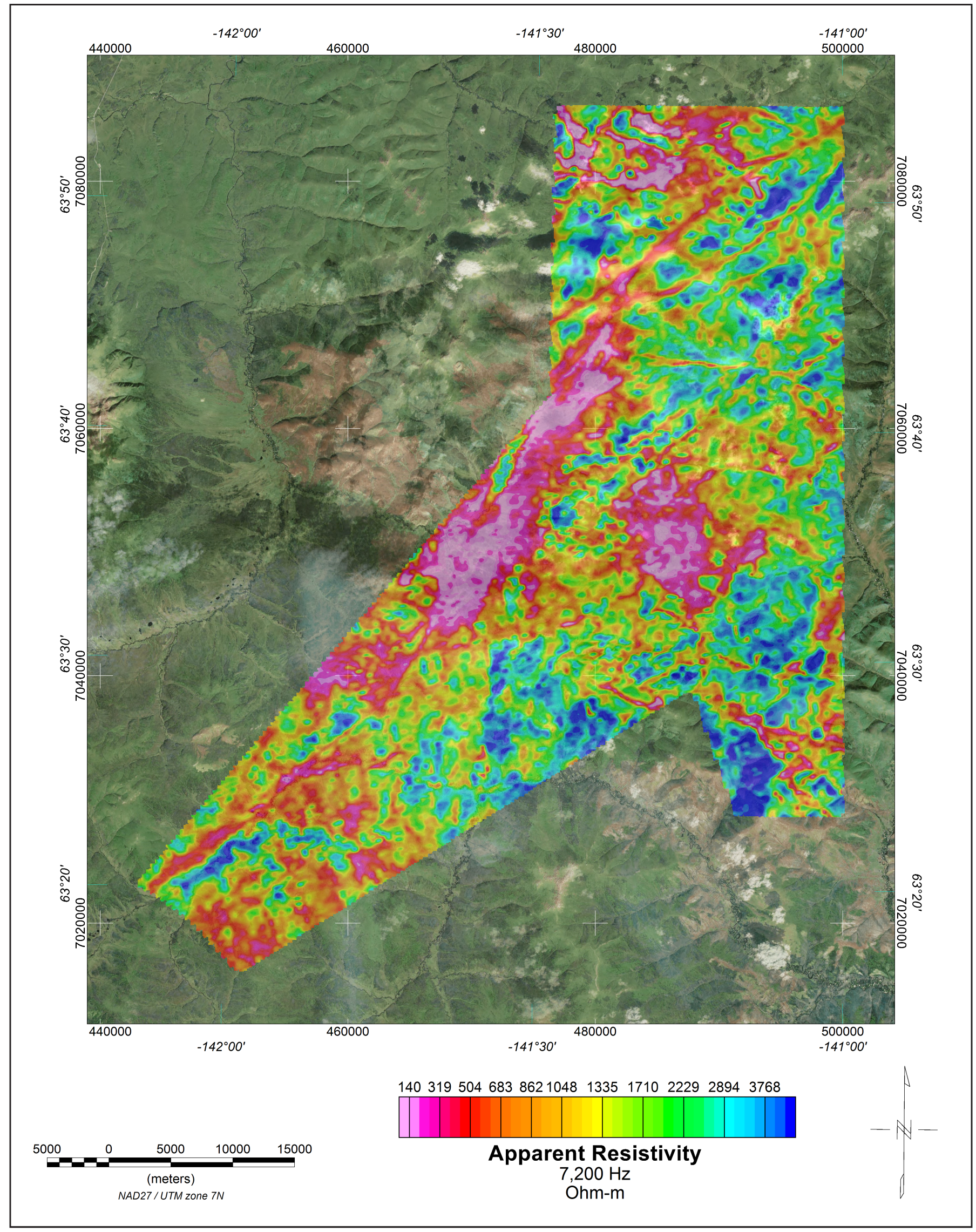

Figure 9.7,200 Hz coplanar apparent resistivity grid with orthometric image. The DIGHEM ${ }^{\vee}$ EM system measured inphase and quadrature components at five frequencies. Two vertical coaxial coil-pairs operated at 1,000 and $5,500 \mathrm{~Hz}$ while three horizontal coplanar coil-pairs operated at $900,7,200$, and $56,000 \mathrm{~Hz}$. EM data were sampled at 0.1 second intervals. The EM system responds to bedrock conductors, conductive overburden, and cultural sources. Apparent resistivity is generated from the inphase and quadrature component of the coplanar $7,200 \mathrm{~Hz}$ using the pseudo-layer half space model. The data were interpolated onto a regular $80 \mathrm{~m}$ grid using a modified Akima (1970) technique. 


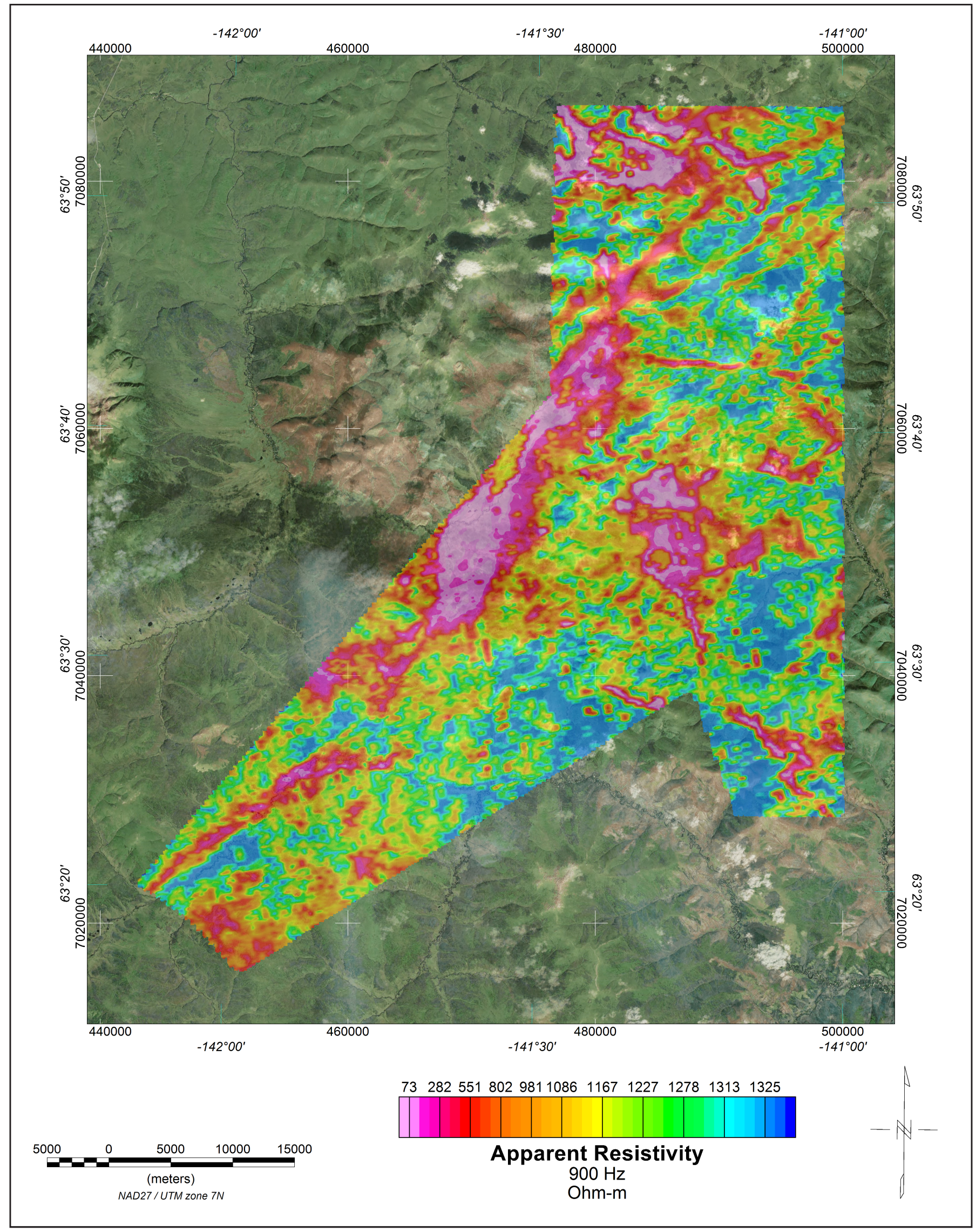

Figure $10.900 \mathrm{~Hz}$ coplanar apparent resistivity grid with orthometric image. The DIGHEM ${ }^{\vee} E M$ system measured inphase and quadrature components at five frequencies. Two vertical coaxial coil-pairs operated at 1,000 and $5,500 \mathrm{~Hz}$ while three horizontal coplanar coil-pairs operated at $900,7,200$, and $56,000 \mathrm{~Hz}$. EM data were sampled at 0.1 second intervals. The EM system responds to bedrock conductors, conductive overburden, and cultural sources. Apparent resistivity is generated from the inphase and quadrature component of the coplanar $900 \mathrm{~Hz}$ using the pseudo-layer half space model. The data were interpolated onto a regular $80 \mathrm{~m}$ grid using a modified Akima (1970) technique. 
Table 1. Copies of the following maps are included at the end of this booklet. The low-resolution, page-size maps included in this booklet are intended to be used as a search tool and are not the final product. Large-scale, full-resolution versions of each map are available to download on this publication's citation page: $\mathrm{http}: / /$ doi.org/10.14509/30261

\begin{tabular}{|c|c|}
\hline Map Title & Description \\
\hline ladue_residualmag_topo_map_1 of2.pdf & residual magnetic field grid with topographic base map \\
\hline ladue_residualmag_topo_map_2of2.pdf & residual magnetic field grid with topographic base map \\
\hline $\begin{array}{l}\text { ladue_residualmag_contours_plss_map_1of2. } \\
\text { pdf }\end{array}$ & $\begin{array}{l}\text { residual magnetic field grid and contours with public land survey system base } \\
\text { layer }\end{array}$ \\
\hline $\begin{array}{l}\text { ladue_residualmag_contours_plss_map_2of2. } \\
\text { pdf }\end{array}$ & $\begin{array}{l}\text { residual magnetic field grid and contours with public land survey system base } \\
\text { layer }\end{array}$ \\
\hline ladue_calculated1vd_topo_map_1of2.pdf & calculated first vertical derivative grid with topographic base map \\
\hline ladue_calculated1vd_topo_map_2of2.pdf & calculated first vertical derivative grid with topographic base map \\
\hline ladue_analyticsignal_topo_map_1of2.pdf & $\begin{array}{l}\text { EM anomaly map with simulated magnetic total field grid contours and public } \\
\text { land survey system base layer }\end{array}$ \\
\hline ladue_analyticsignal_topo_map_2of2.pdf & $\begin{array}{l}\text { EM anomaly map with simulated magnetic total field grid contours and public } \\
\text { land survey system base layer }\end{array}$ \\
\hline $\begin{array}{l}\text { ladue_analyticsignal_contours_plss_ } \\
\text { map_1of2.pdf }\end{array}$ & $\begin{array}{l}\text { EM anomaly map with simulated magnetic total field grid contours and topo- } \\
\text { graphic base map }\end{array}$ \\
\hline $\begin{array}{l}\text { ladue_analyticsignal_contours_plss_ } \\
\text { map_2of2.pdf }\end{array}$ & $\begin{array}{l}\text { EM anomaly map with simulated magnetic total field grid contours and topo- } \\
\text { graphic base map }\end{array}$ \\
\hline $\begin{array}{l}\text { ladue_tiltderivative_contours_topo_ } \\
\text { map_1 of2.pdf }\end{array}$ & $\begin{array}{l}\text { EM anomaly map with simulated magnetic total field grid contours and topo- } \\
\text { graphic base map }\end{array}$ \\
\hline $\begin{array}{l}\text { ladue_tiltderivative_contours_topo_ } \\
\text { map_2of2.pdf }\end{array}$ & $\begin{array}{l}\text { EM anomaly map with simulated magnetic total field grid contours and topo- } \\
\text { graphic base map }\end{array}$ \\
\hline $\begin{array}{l}\text { ladue_residualmag_shaded_tiltderivative_ } \\
\text { contours_topo_map_1of2.pdf }\end{array}$ & $\begin{array}{l}\text { EM anomaly map with simulated magnetic total field grid contours and topo- } \\
\text { graphic base map }\end{array}$ \\
\hline $\begin{array}{l}\text { ladue_residualmag_shaded_tiltderivative_ } \\
\text { contours_topo_map_2of2.pdf }\end{array}$ & $\begin{array}{l}\text { EM anomaly map with simulated magnetic total field grid contours and topo- } \\
\text { graphic base map }\end{array}$ \\
\hline ladue_res56khz_topo_map_1of2.pdf & $56,000 \mathrm{~Hz}$ apparent resistivity grid with topographic base map \\
\hline ladue_res56khz_topo_map_2of2.pdf & $56,000 \mathrm{~Hz}$ apparent resistivity grid with topographic base map \\
\hline ladue_res56khz_contours_plss_map_1of2.pdf & $\begin{array}{l}56,000 \mathrm{~Hz} \text { apparent resistivity grid with contours and public land survey system } \\
\text { base layer }\end{array}$ \\
\hline
\end{tabular}


Table 1, continued. Copies of the following maps are included at the end of this booklet. The low-resolution, page-size maps included in this booklet are intended to be used as a search tool and are not the final product. Large-scale, full-resolution versions of each map are available to download on this publication's citation page: $\underline{\text { http://doi.org/10.14509/30261 }}$

\begin{tabular}{|c|c|}
\hline Map Title & Description \\
\hline ladue_res56khz_contours_plss_map_2of2.pdf & $\begin{array}{l}56,000 \mathrm{~Hz} \text { apparent resistivity grid with contours and public land survey system } \\
\text { base layer }\end{array}$ \\
\hline ladue_res7200hz_topo_map_1 of2.pdf & $7,200 \mathrm{~Hz}$ apparent resistivity grid with topographic base map \\
\hline ladue_res7200hz_topo_map_2of2.pdf & 7,200 Hz apparent resistivity grid with topographic base map \\
\hline $\begin{array}{l}\text { ladue_res7200hz_contours_plss_map_1of2. } \\
\text { pdf }\end{array}$ & $\begin{array}{l}\text { 7,200 Hz apparent resistivity grid with contours and public land survey system } \\
\text { base layer }\end{array}$ \\
\hline $\begin{array}{l}\text { ladue_res7200hz_contours_plss_map_2of2. } \\
\text { pdf }\end{array}$ & $\begin{array}{l}\text { 7,200 Hz apparent resistivity grid with contours and public land survey system } \\
\text { base layer }\end{array}$ \\
\hline ladue_res900hz_topo_map_1of2.pdf & $900 \mathrm{~Hz}$ apparent resistivity grid with topographic base map \\
\hline ladue_res900hz_topo_map_2of2.pdf & $900 \mathrm{~Hz}$ apparent resistivity grid with topographic base map \\
\hline ladue_res900hz_contours_plss_map_1of2.pdf & $\begin{array}{l}900 \mathrm{~Hz} \text { apparent resistivity grid with contours and public land survey system } \\
\text { base layer }\end{array}$ \\
\hline ladue_res900hz_contours_plss_map_2of2.pdf & $\begin{array}{l}900 \mathrm{~Hz} \text { apparent resistivity grid with contours and public land survey system } \\
\text { base layer }\end{array}$ \\
\hline ladue_interpretation_plss_map_1of2.pdf & $\begin{array}{l}\text { interpretation based on geophysical data with public land survey system base } \\
\text { layer }\end{array}$ \\
\hline ladue_interpretation_plss_map_2of2.pdf & $\begin{array}{l}\text { interpretation based on geophysical data with public land survey system base } \\
\text { layer }\end{array}$ \\
\hline $\begin{array}{l}\text { ladue_interpretation_residualmag_plss_ } \\
\text { map_1 of2.pdf }\end{array}$ & $\begin{array}{l}\text { interpretation based on geophysical data with residual magnetic field grid and } \\
\text { public land survey system base layer }\end{array}$ \\
\hline $\begin{array}{l}\text { ladue_interpretation_residualmag_plss_ } \\
\text { map_2of2.pdf }\end{array}$ & $\begin{array}{l}\text { interpretation based on geophysical data with residual magnetic field grid and } \\
\text { public land survey system base layer }\end{array}$ \\
\hline $\begin{array}{l}\text { ladue_emanomalies_residualmag_detailed_ } \\
\text { topo_map_1 of4.pdf }\end{array}$ & $\begin{array}{l}\text { detailed electromagnetic anomaly map with simulated magnetic total field grid } \\
\text { and topographic base map }\end{array}$ \\
\hline $\begin{array}{l}\text { ladue_emanomalies_residualmag_detailed_ } \\
\text { topo_map_2of4.pdf }\end{array}$ & $\begin{array}{l}\text { detailed electromagnetic anomaly map with simulated magnetic total field grid } \\
\text { and topographic base map }\end{array}$ \\
\hline $\begin{array}{l}\text { ladue_emanomalies_residualmag_detailed_ } \\
\text { topo_map_3of4.pdf }\end{array}$ & $\begin{array}{l}\text { detailed electromagnetic anomaly map with simulated magnetic total field grid } \\
\text { and topographic base map }\end{array}$ \\
\hline $\begin{array}{l}\text { ladue_emanomalies_residualmag_detailed_ } \\
\text { topo_map_4of4.pdf }\end{array}$ & $\begin{array}{l}\text { detailed electromagnetic anomaly map with simulated magnetic total field grid } \\
\text { and topographic base map }\end{array}$ \\
\hline
\end{tabular}




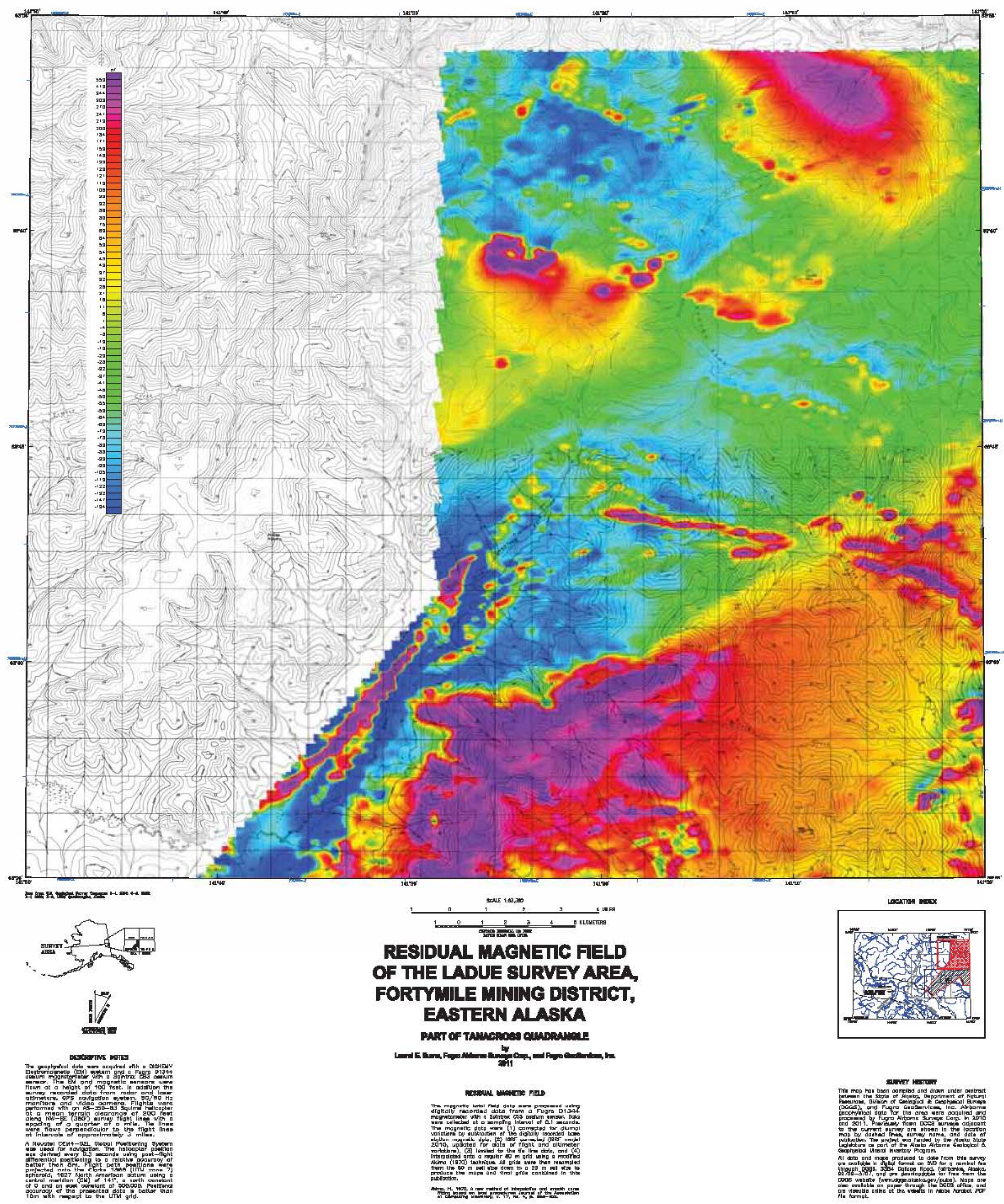




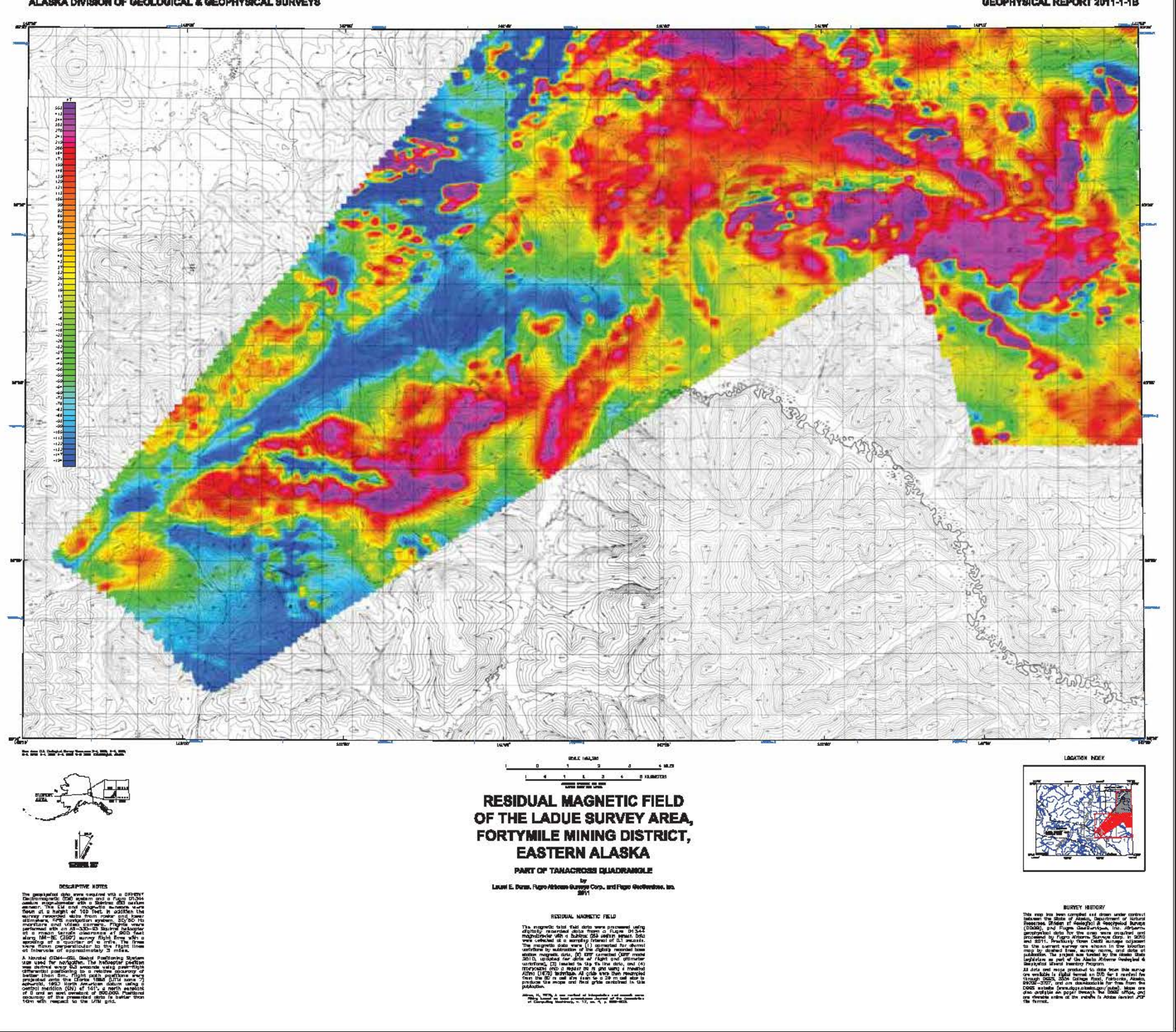




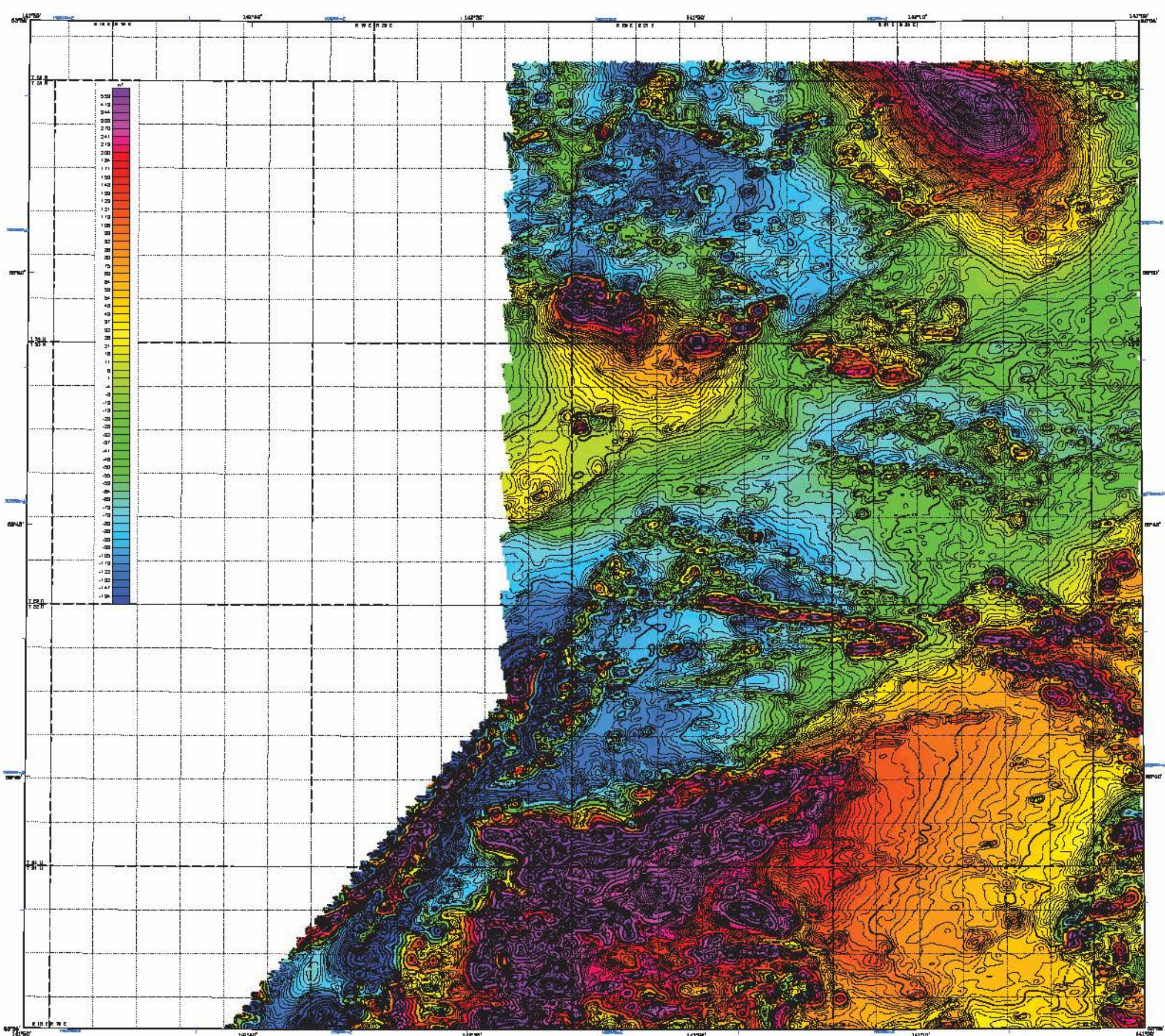

120

$$
\text { (1) }
$$

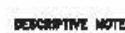

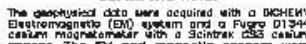

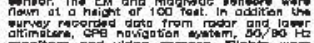

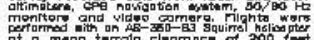

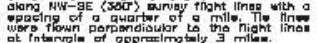

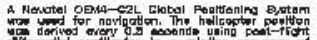

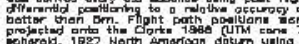

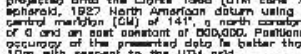

iarsic

$\sin \mid \ln \rightarrow \infty x$

RESIDUAL MAGNETIC FIELD AND DATA CONTOURS OF THE LADUE SURVEY AREA FORTYMILE MINING DISTRICT, EASTERN ALASKA

PART of TAuAcroes oundener

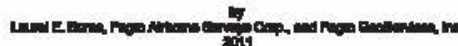

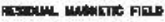

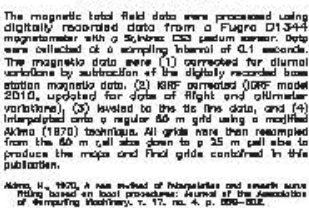

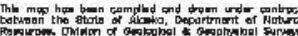

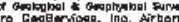

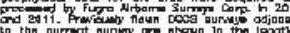
政

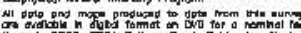

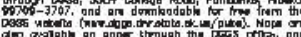

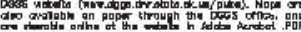




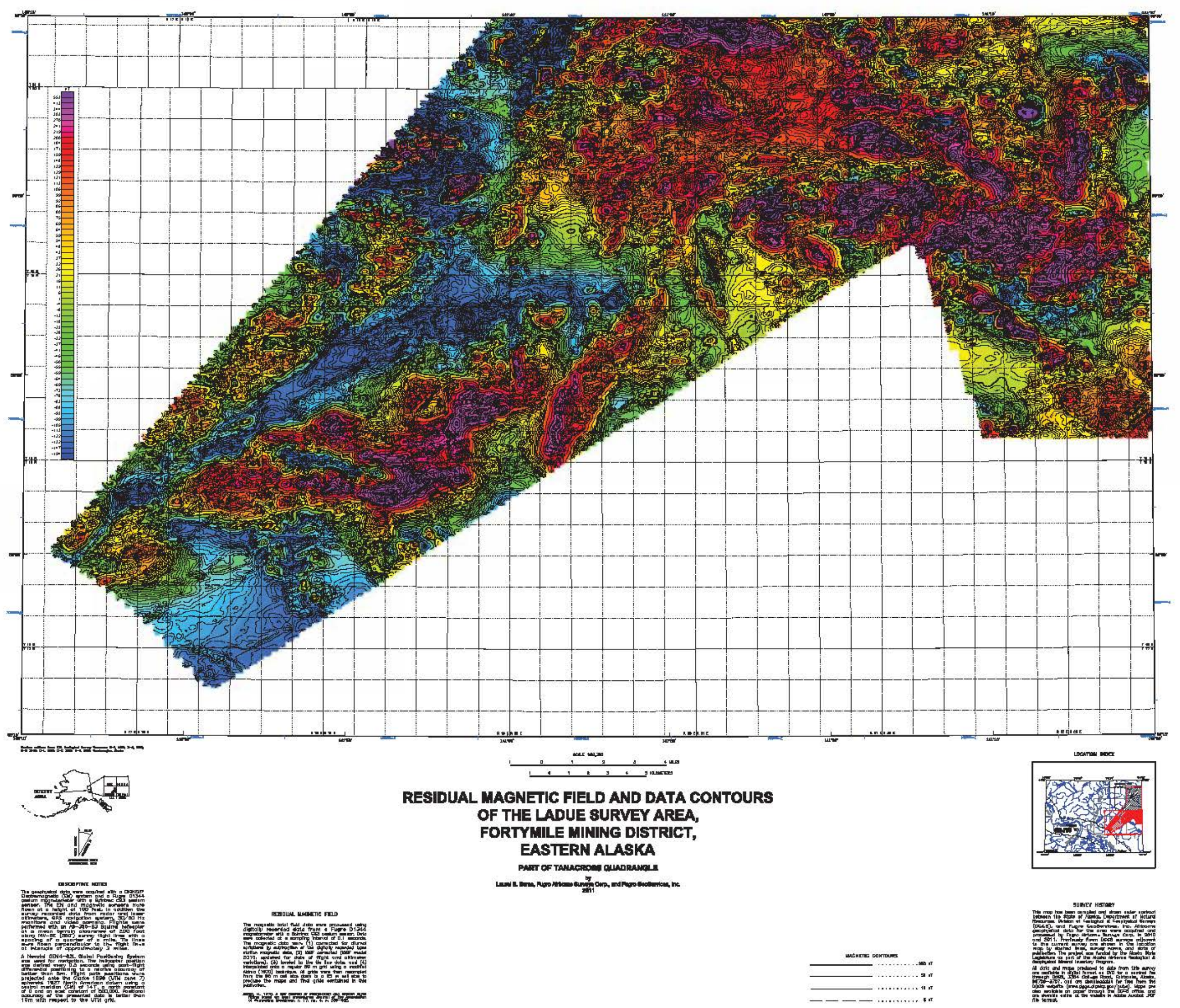




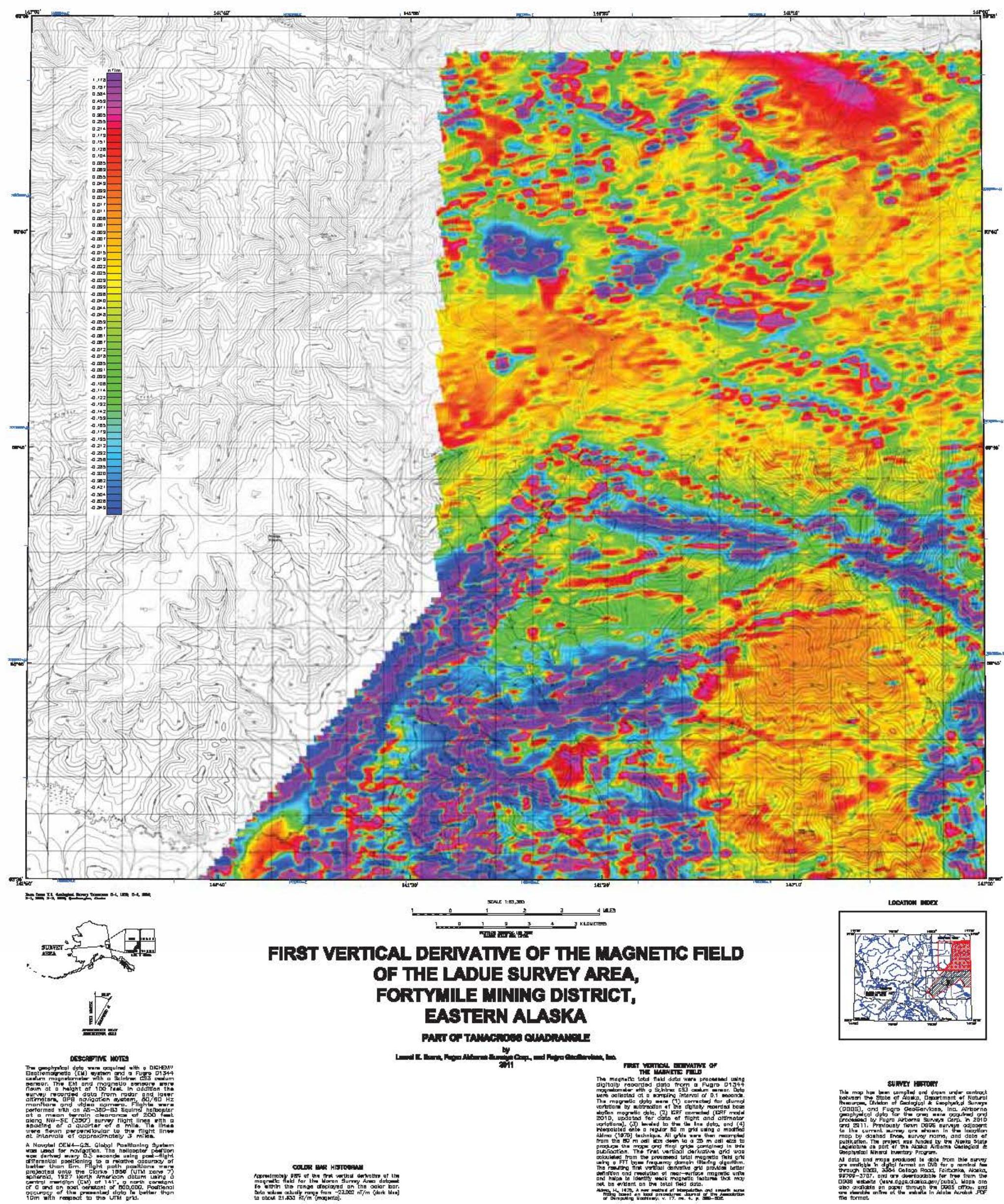




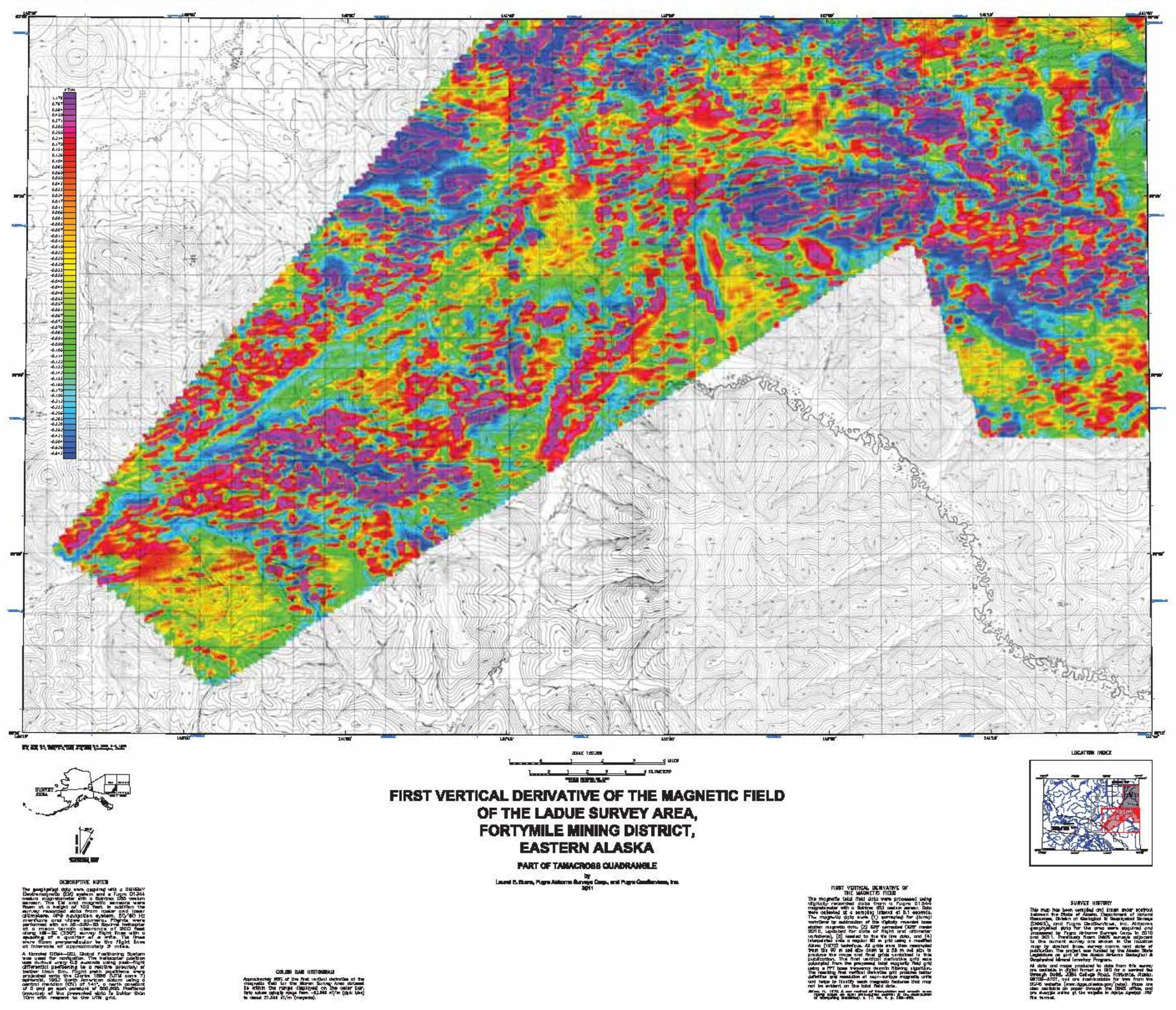




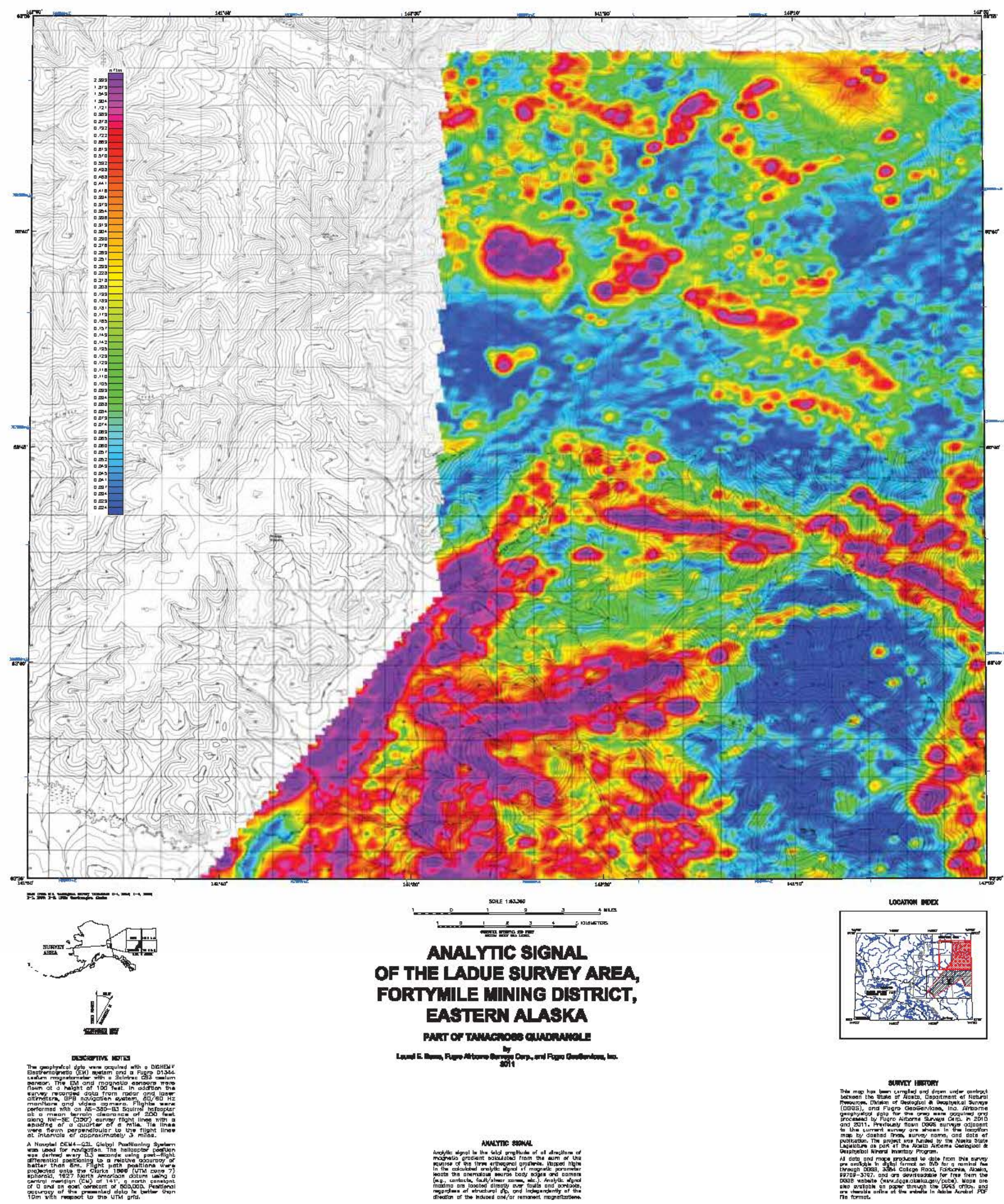




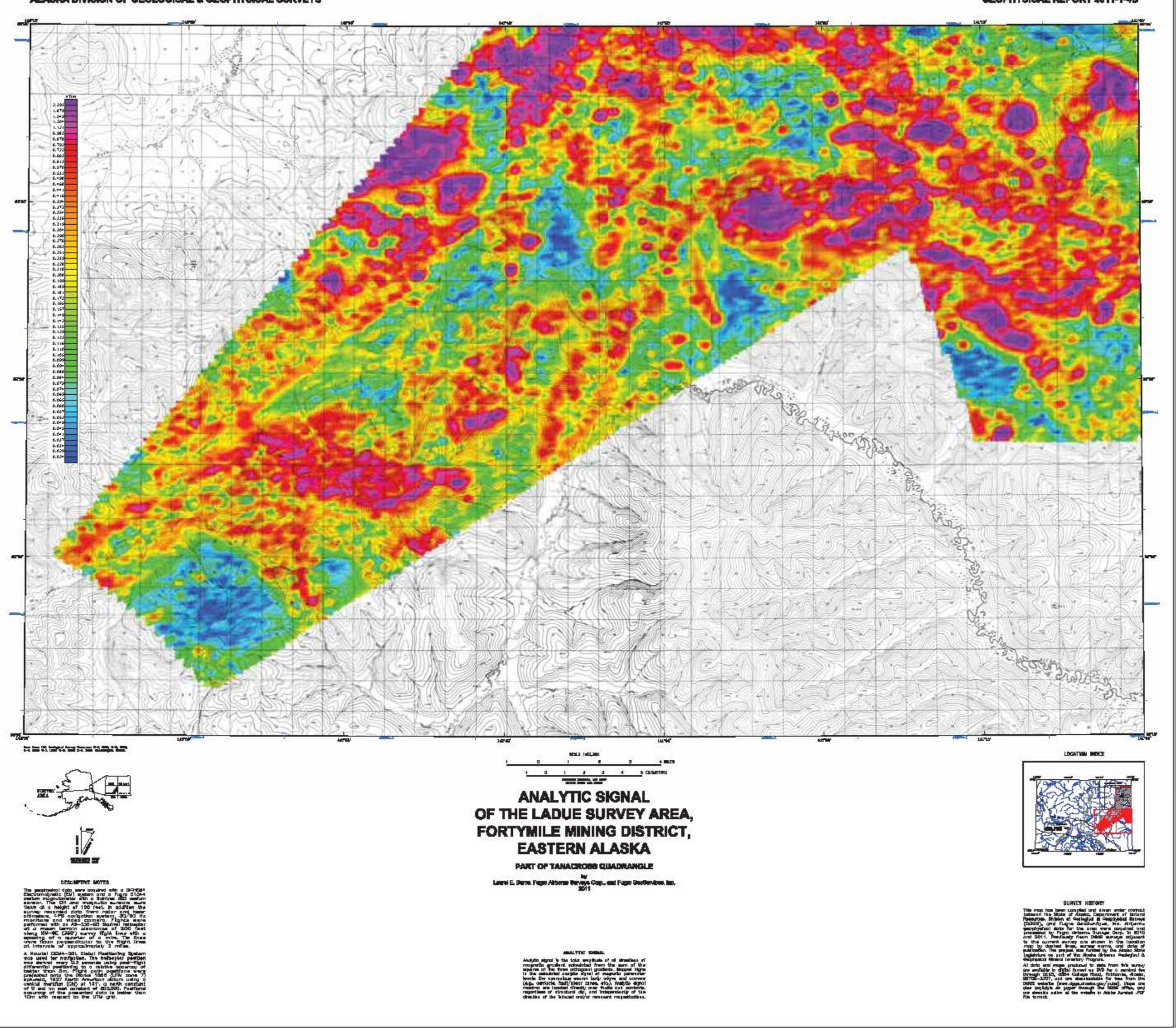



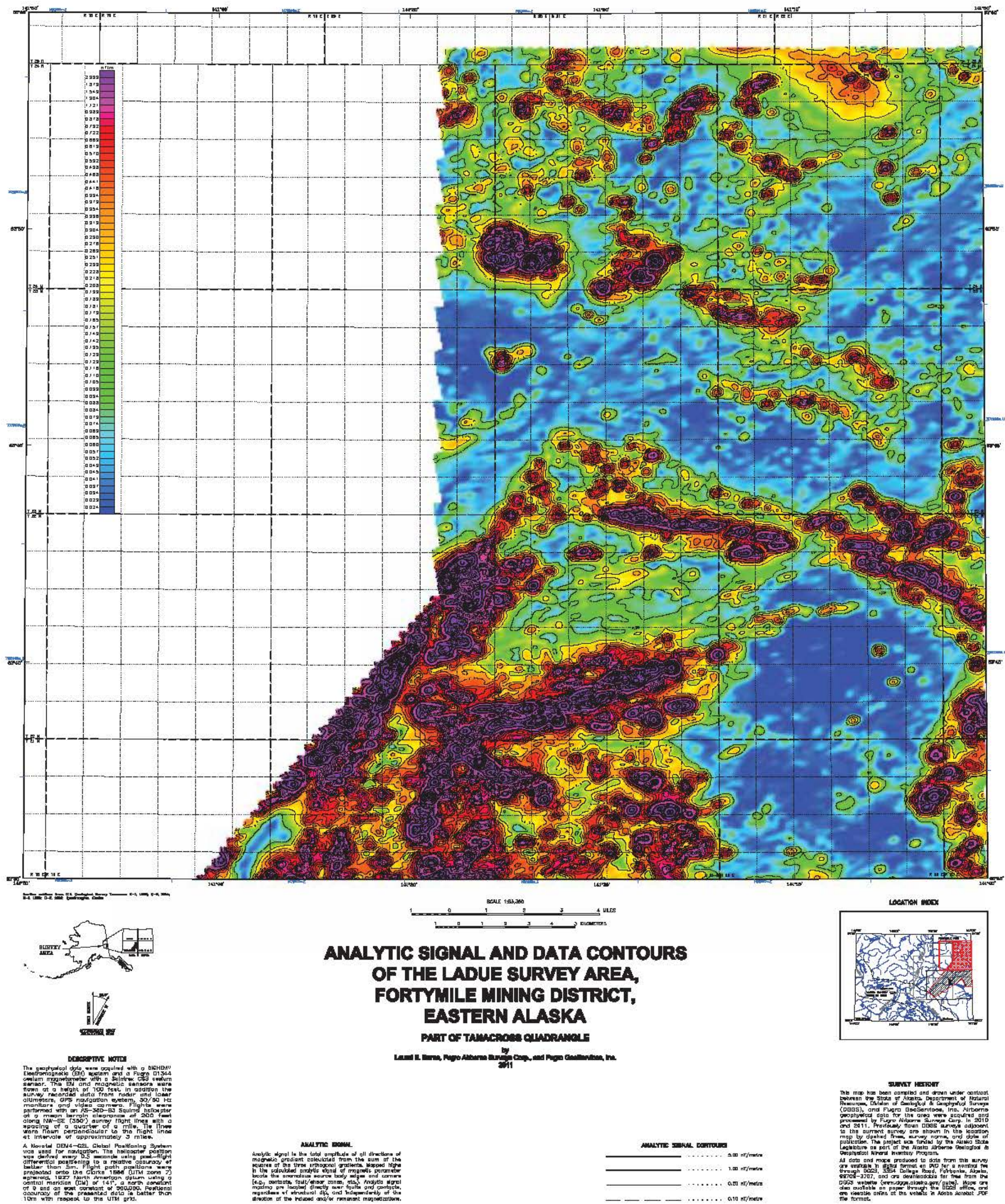

sani kexpm

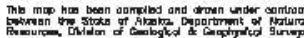

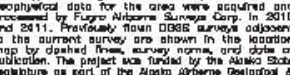

Musme Dowi.

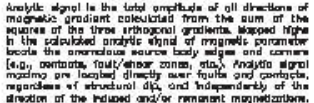

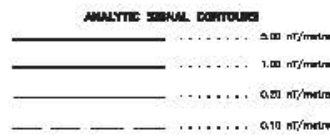

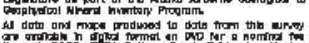

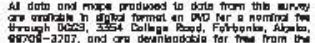

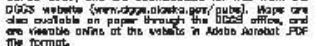




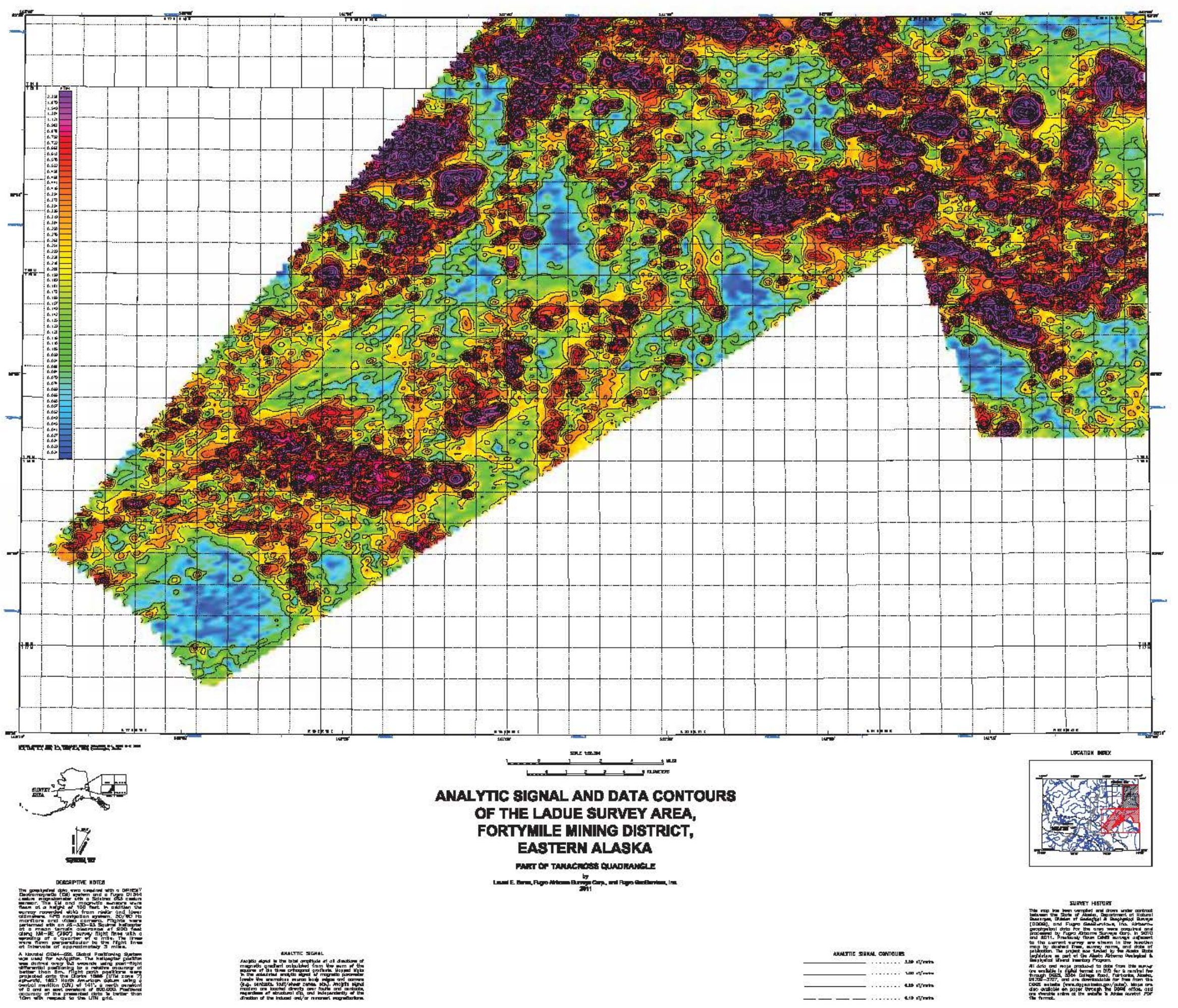




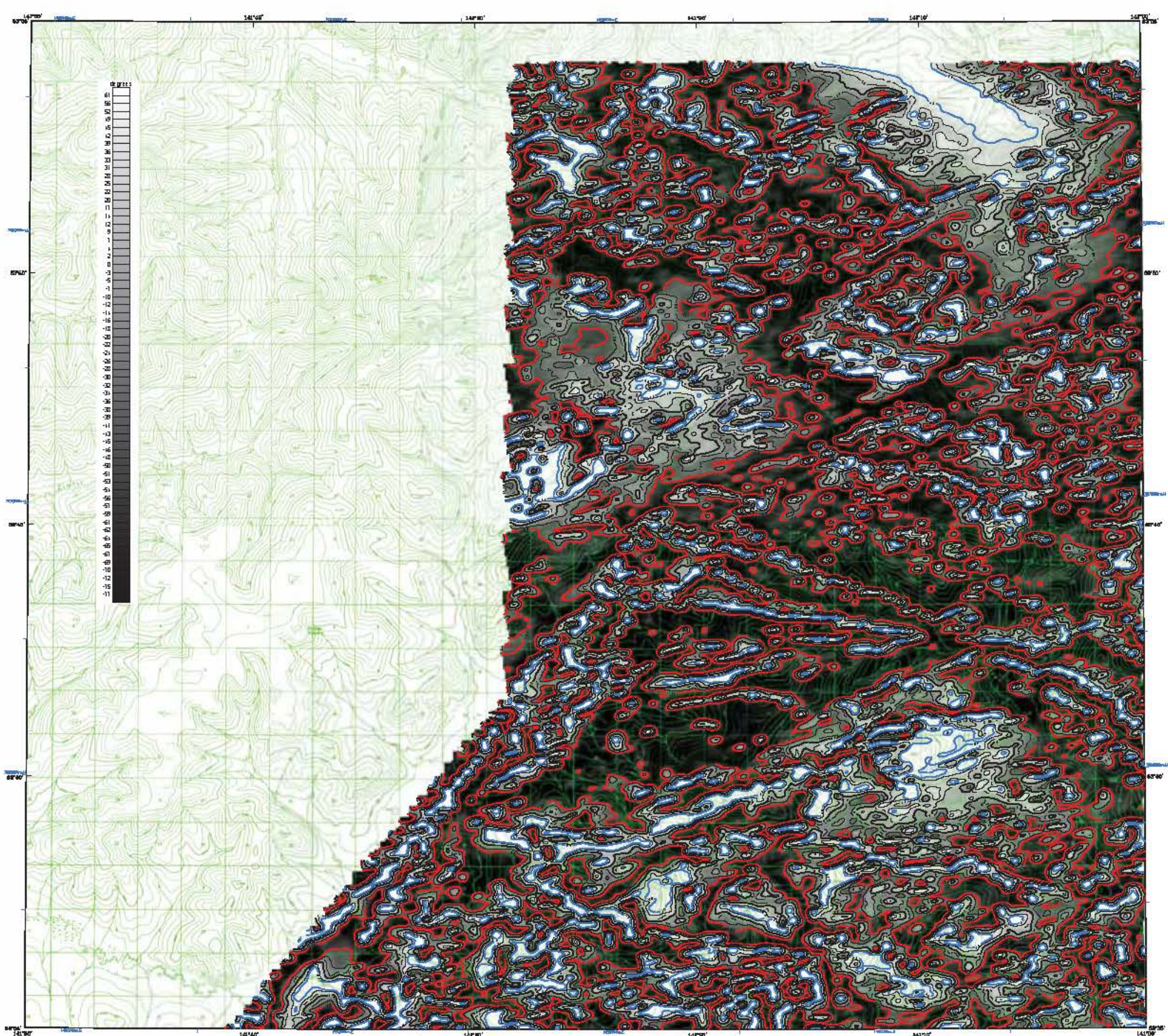

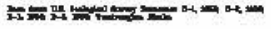

$$
\text { (1) }
$$

mociorme wort

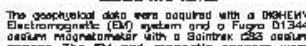
nom ot

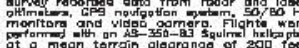

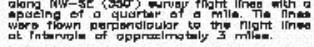

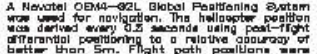

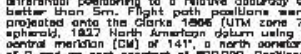

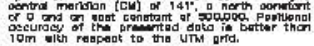

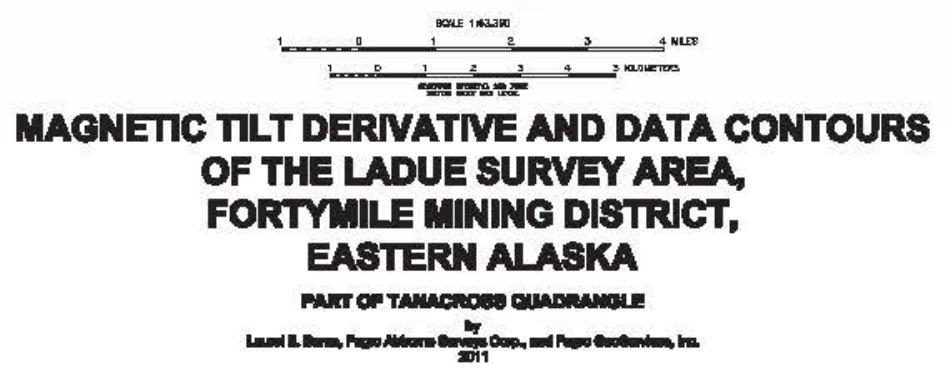

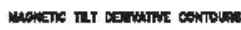

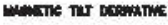

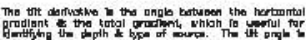

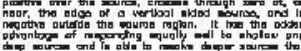

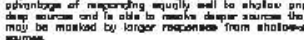

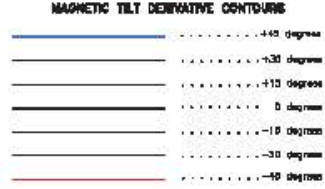

LeCneN INBEX

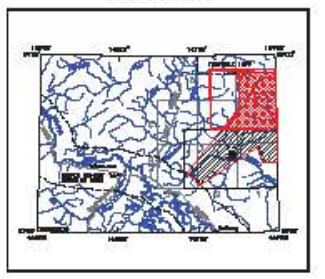

sancy Horomy

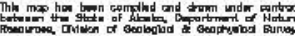

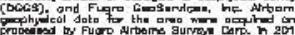

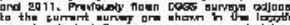

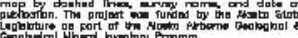

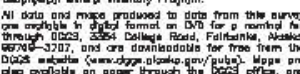

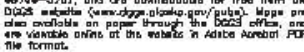




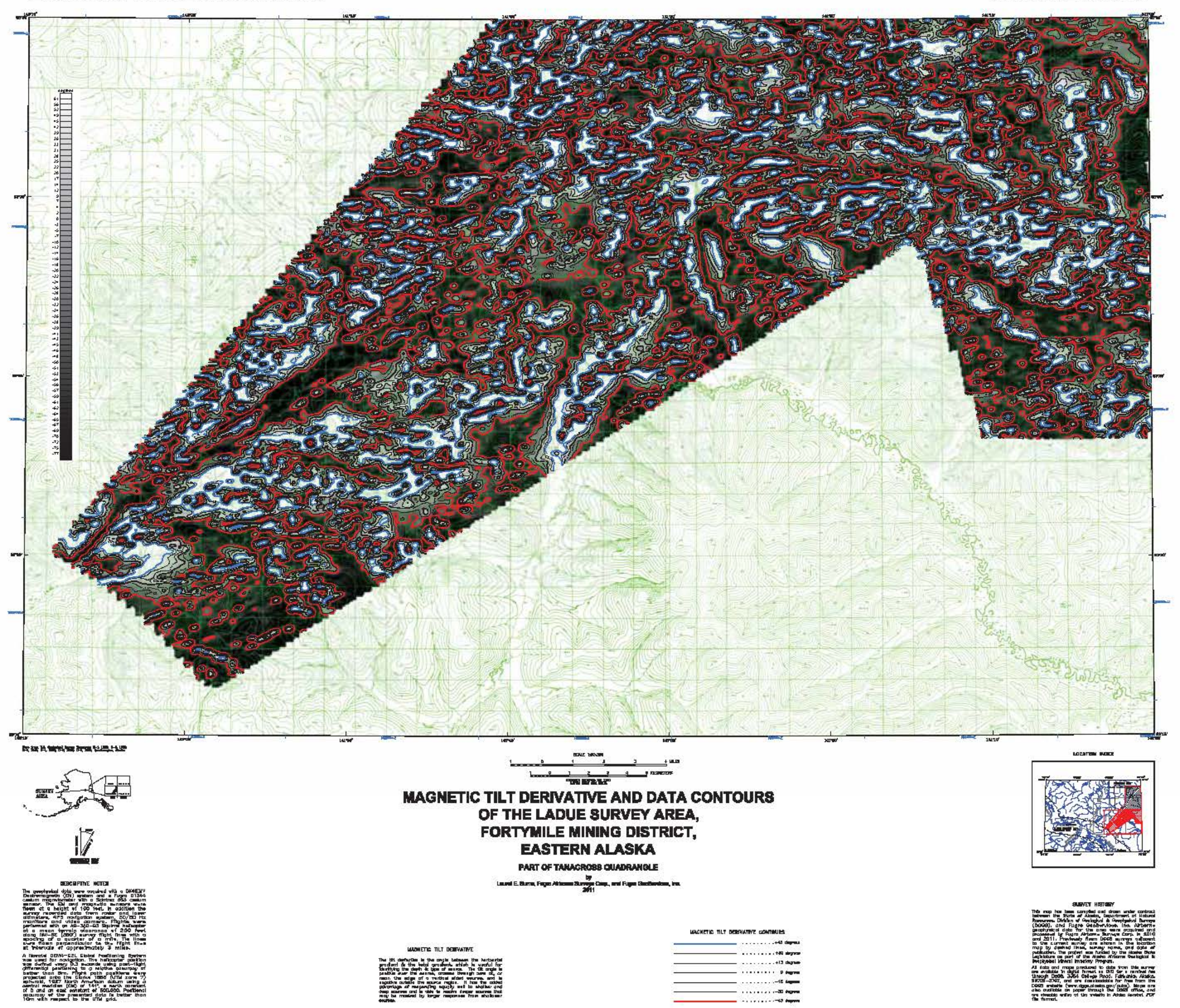




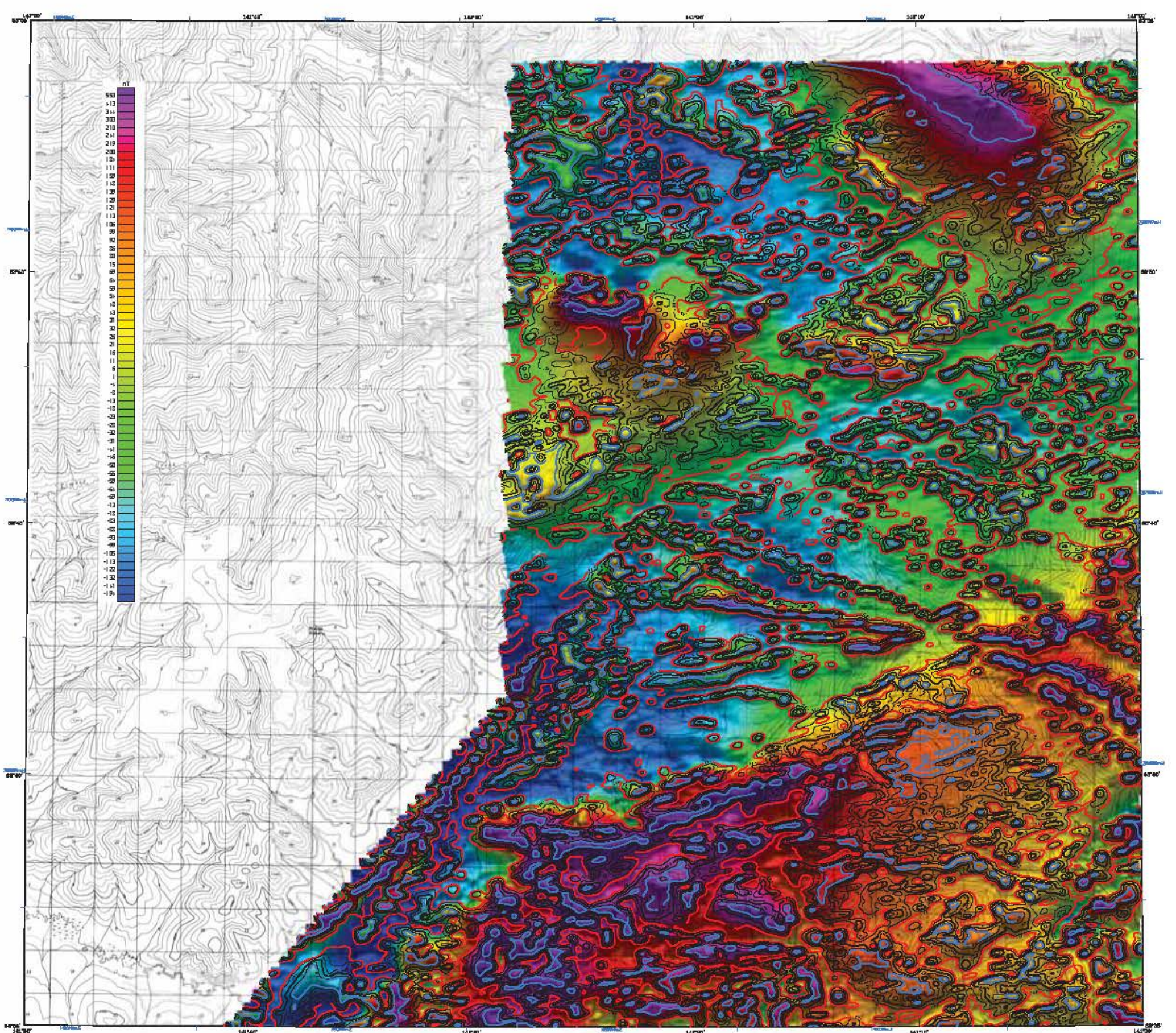

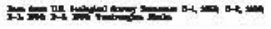

$$
\text { ( }
$$

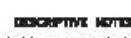

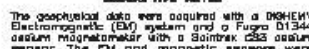

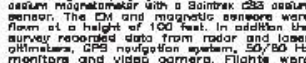

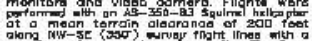

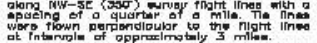

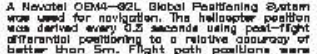

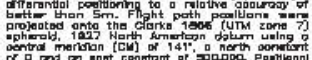

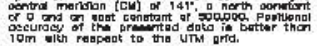

1srm'

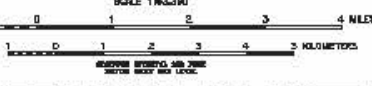

\section{COLOR SHADOW RESIDUAL MACNETIC FIELD WTH MAGNETIC TILT DERNATIVE DATA CONTOURS OF THE LADUE SURVEY AREA, FORTYIILE AINING DISTRICT, EASTERN ALASKA}

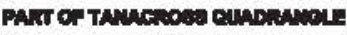

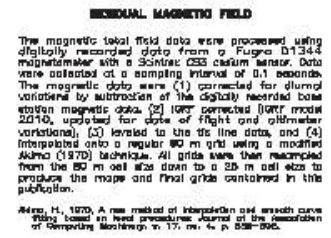

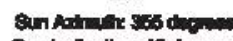
Bun inchethere 45 deoren

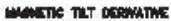

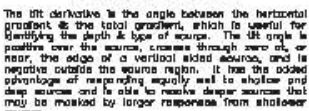

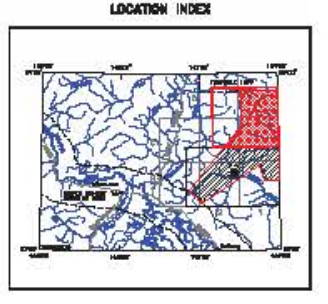

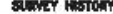

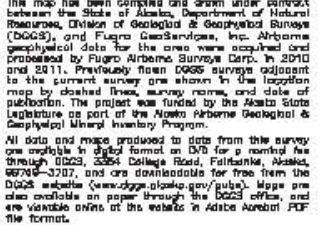

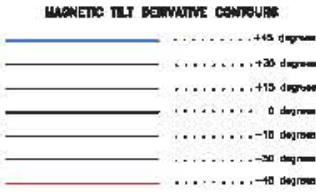

ingrom 


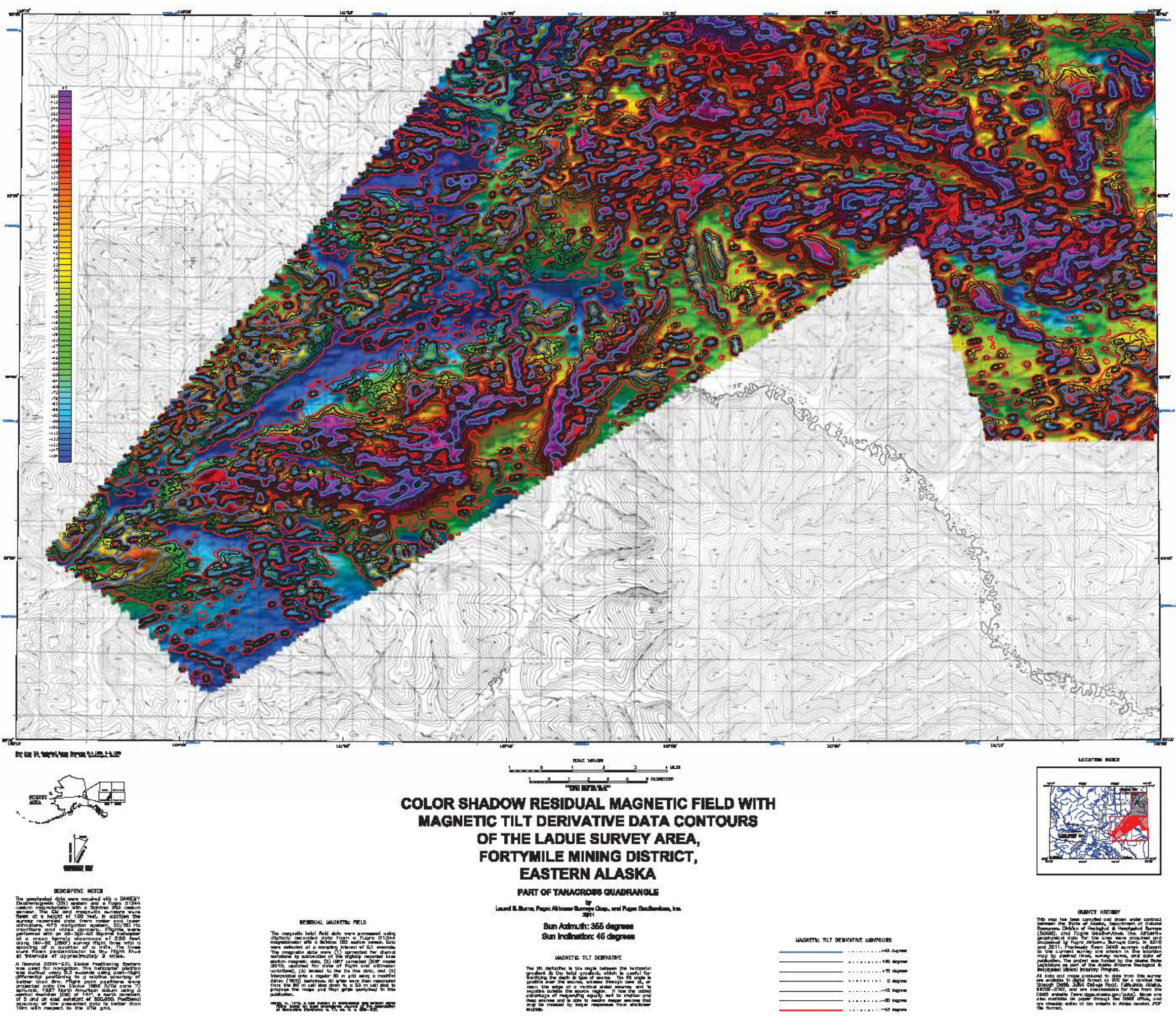




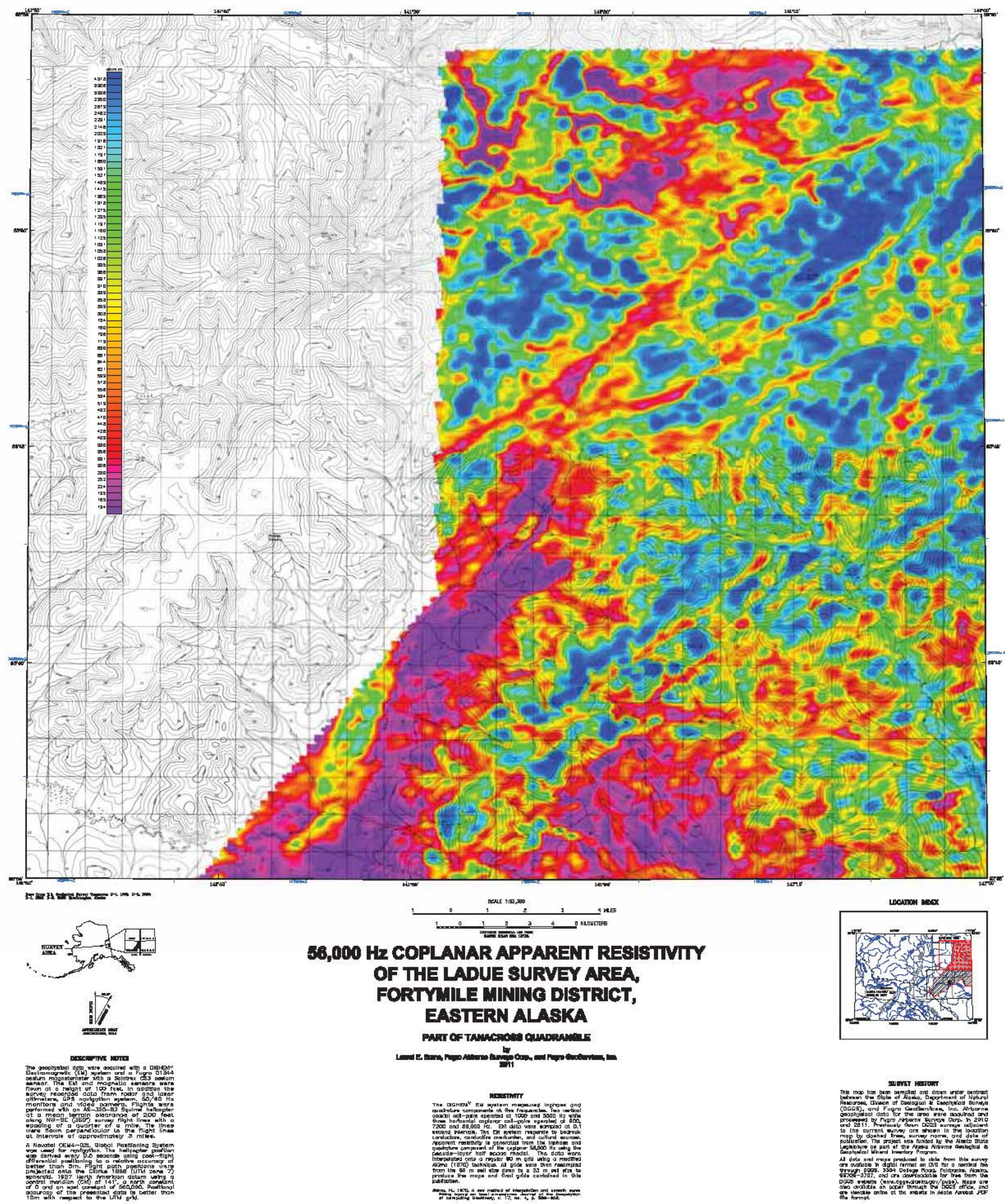




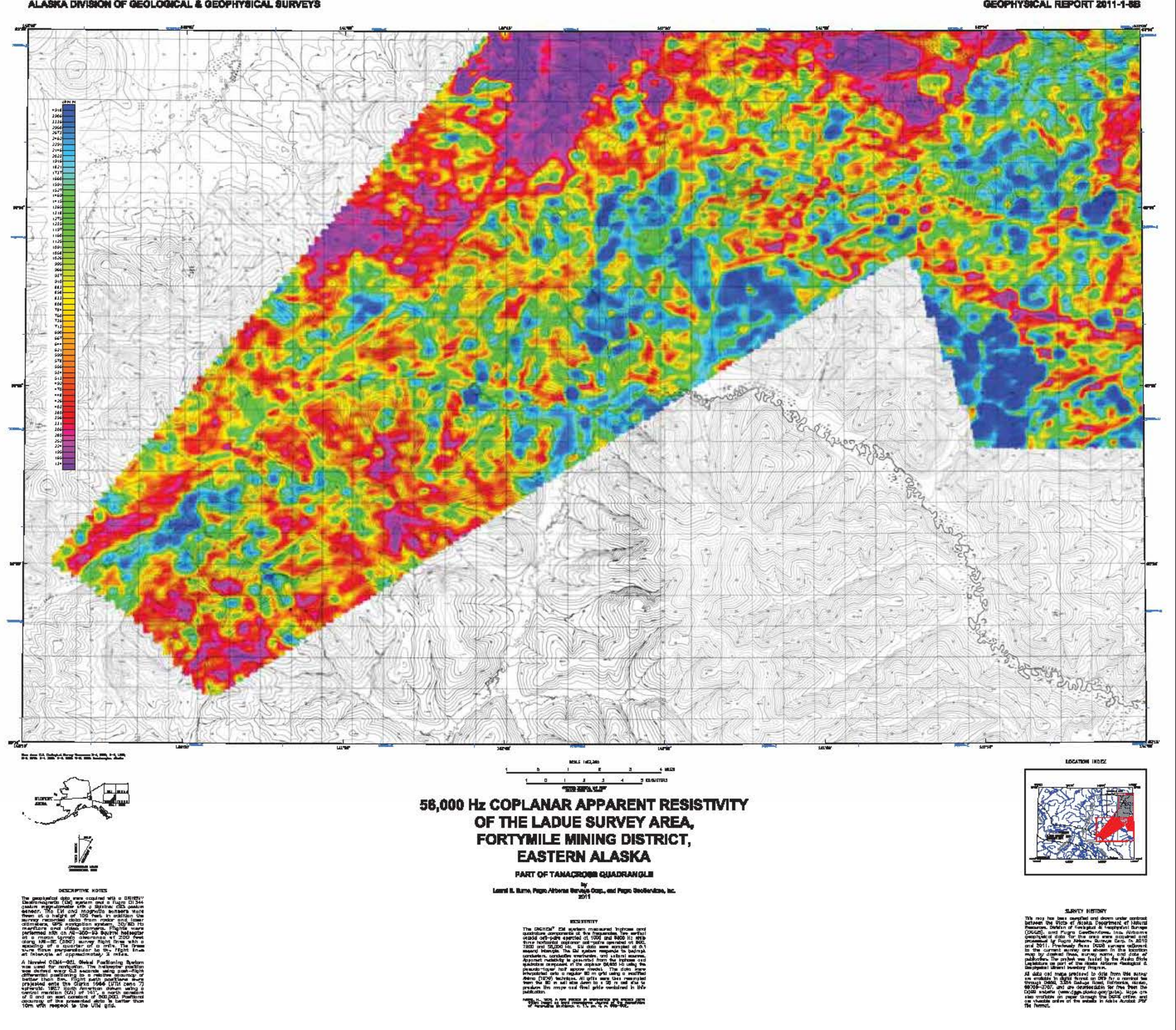




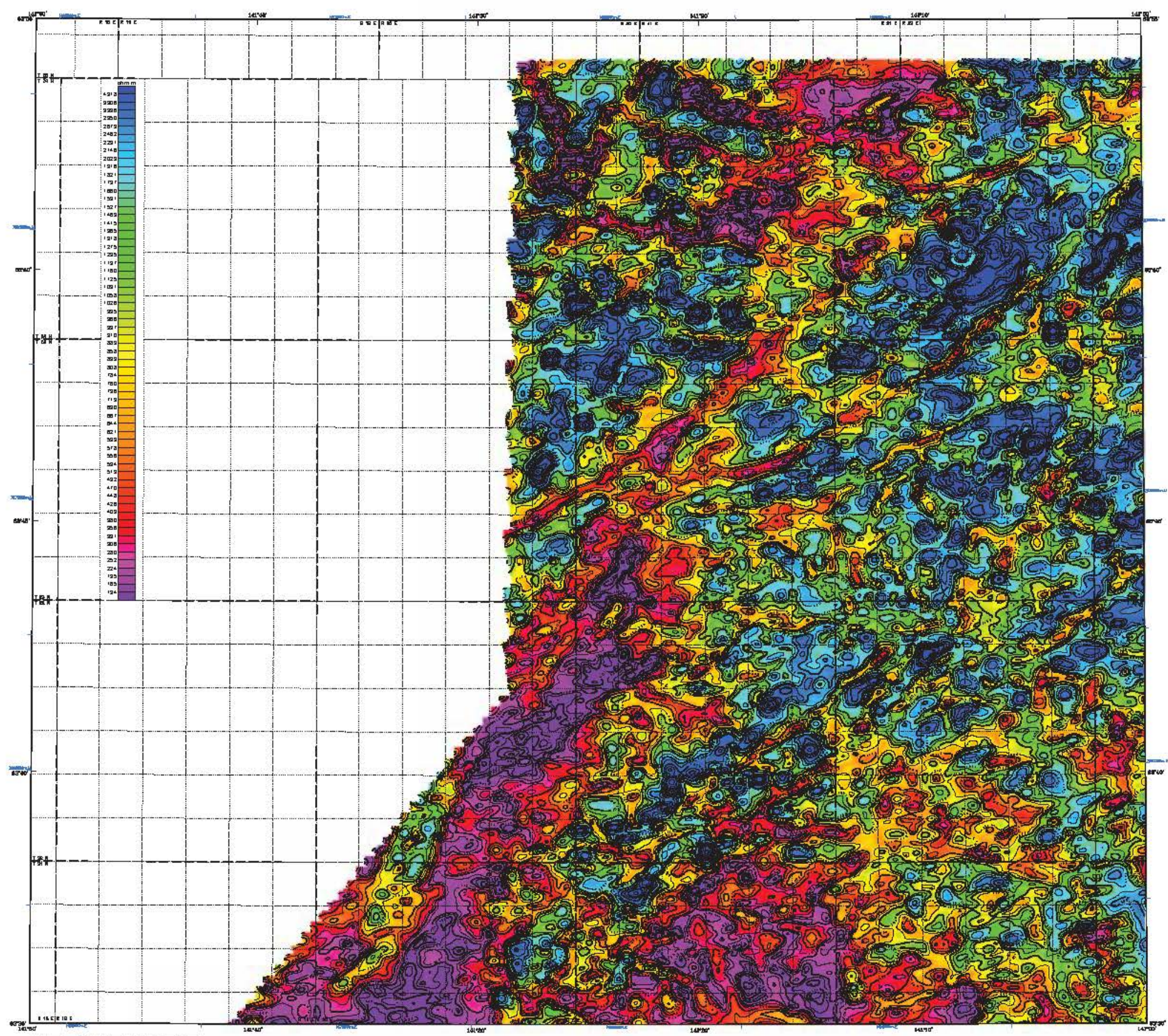

Tre

...

$$
\text { 粦 }
$$

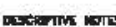

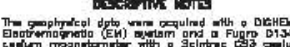
thenctions

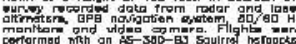

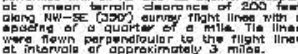

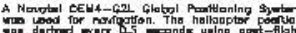
1.

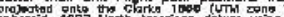

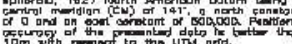

56,000 Hz COPLANAR APPARENT RESISTIVITY AND DATA CONTOURS OF THE LADUE SURVEY AREA, FORTYMILE MINING DISTRICT, EASTERN ALASKA

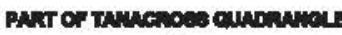

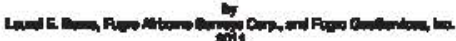

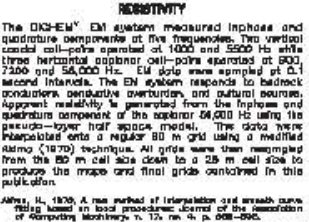

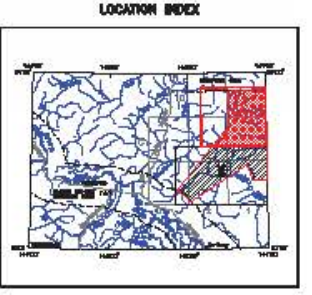

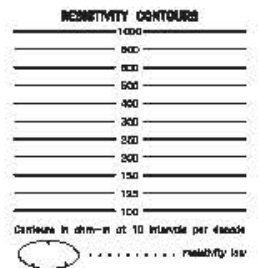

sunve Herom

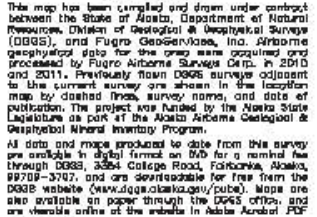




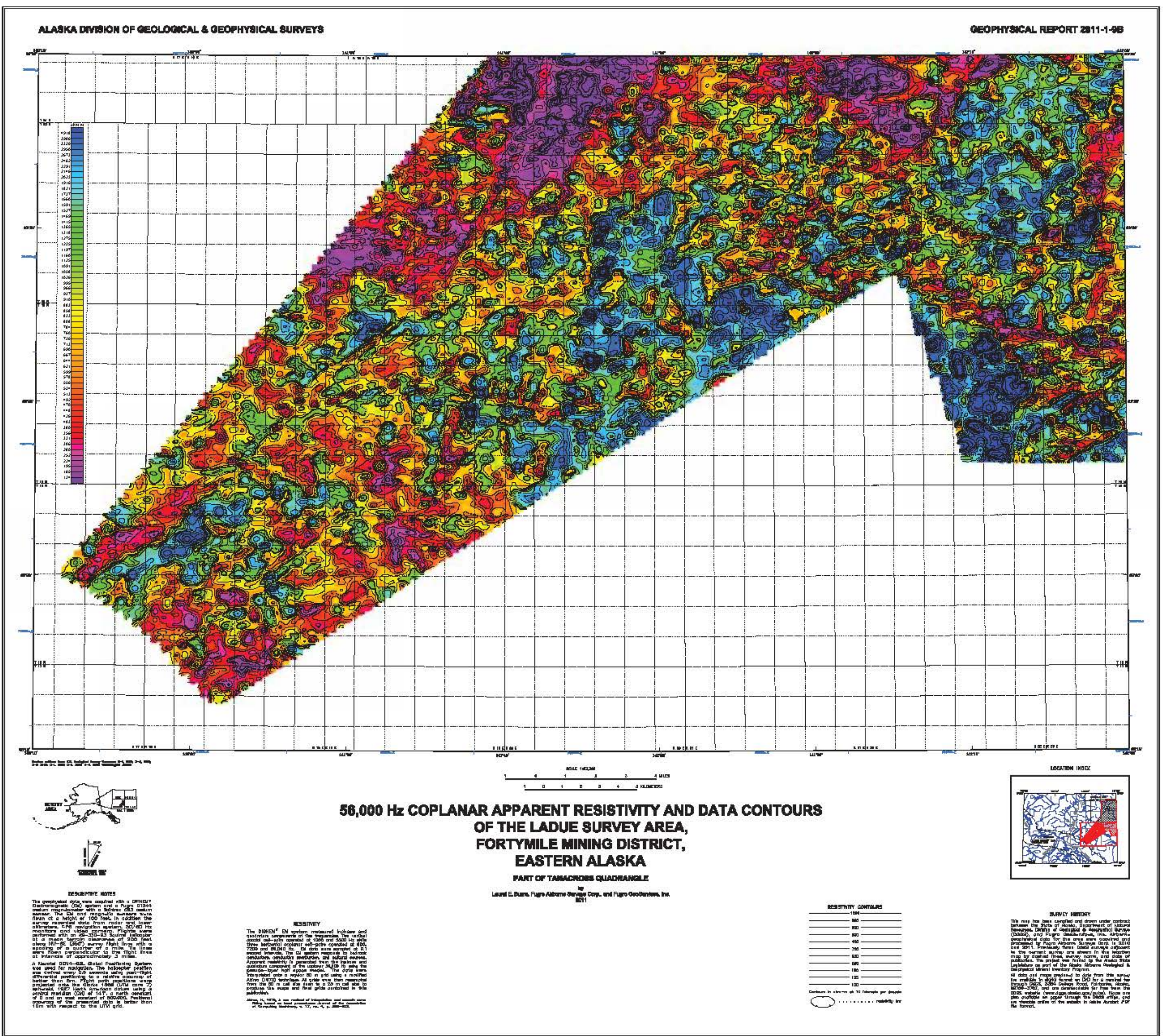




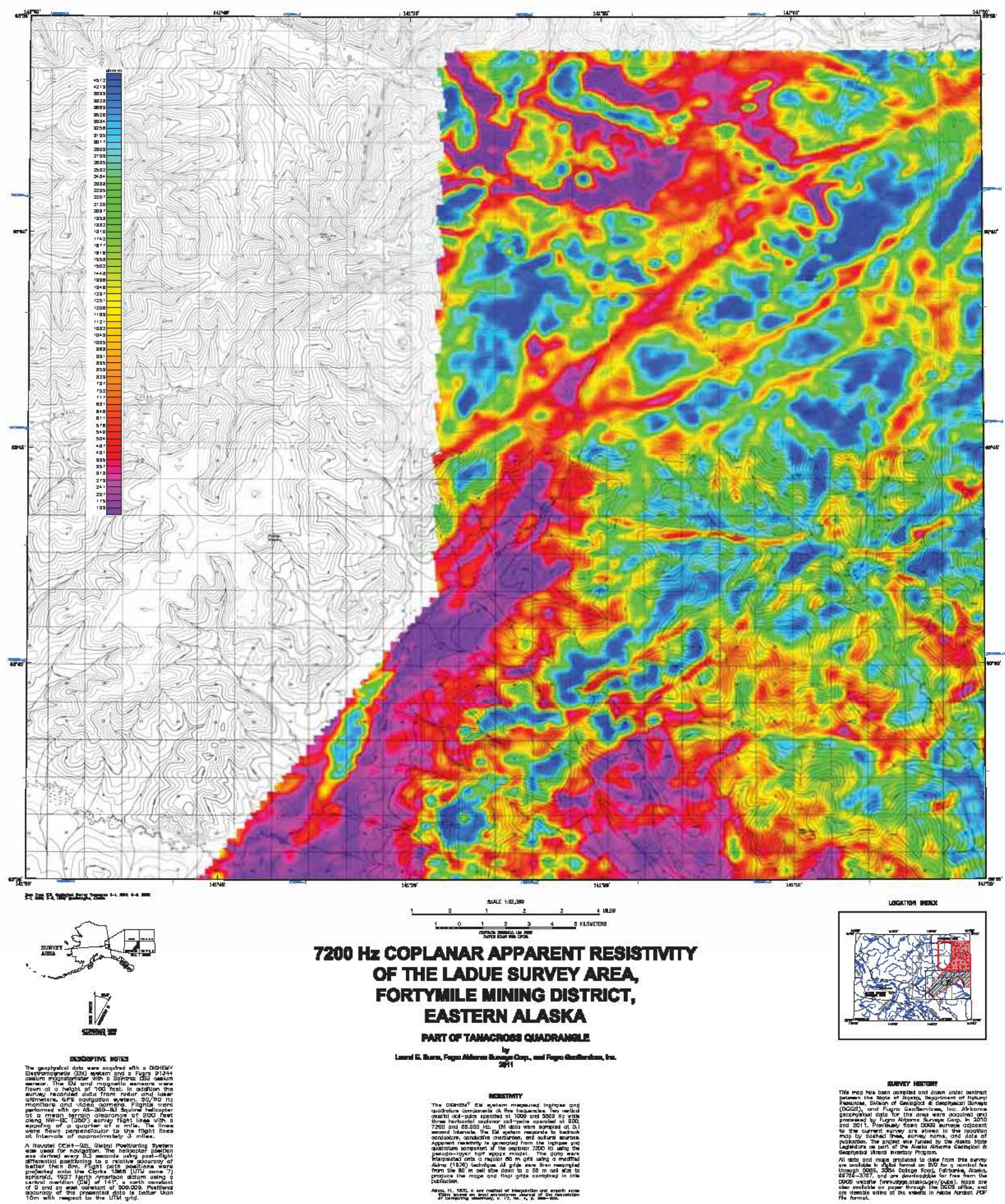




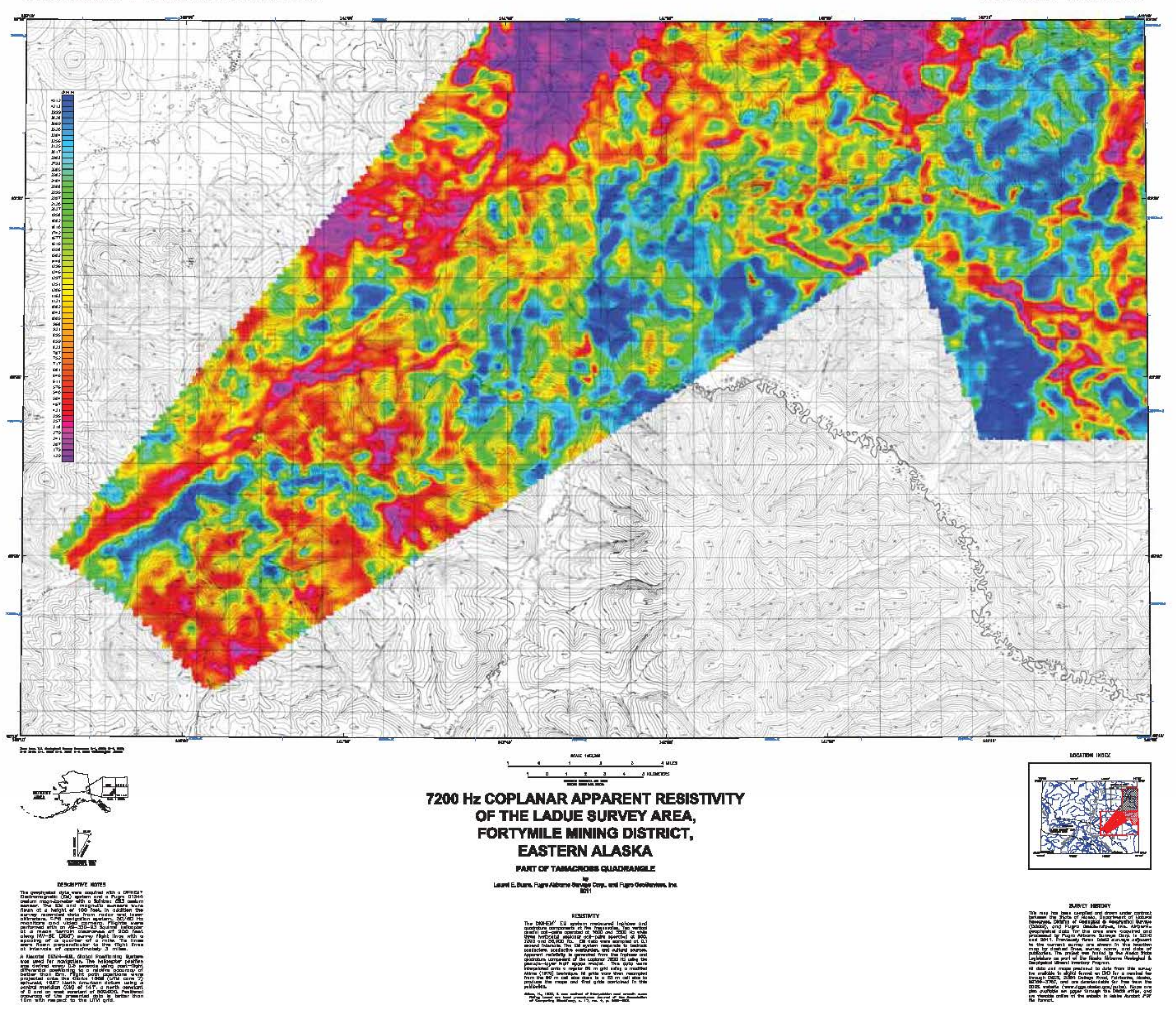




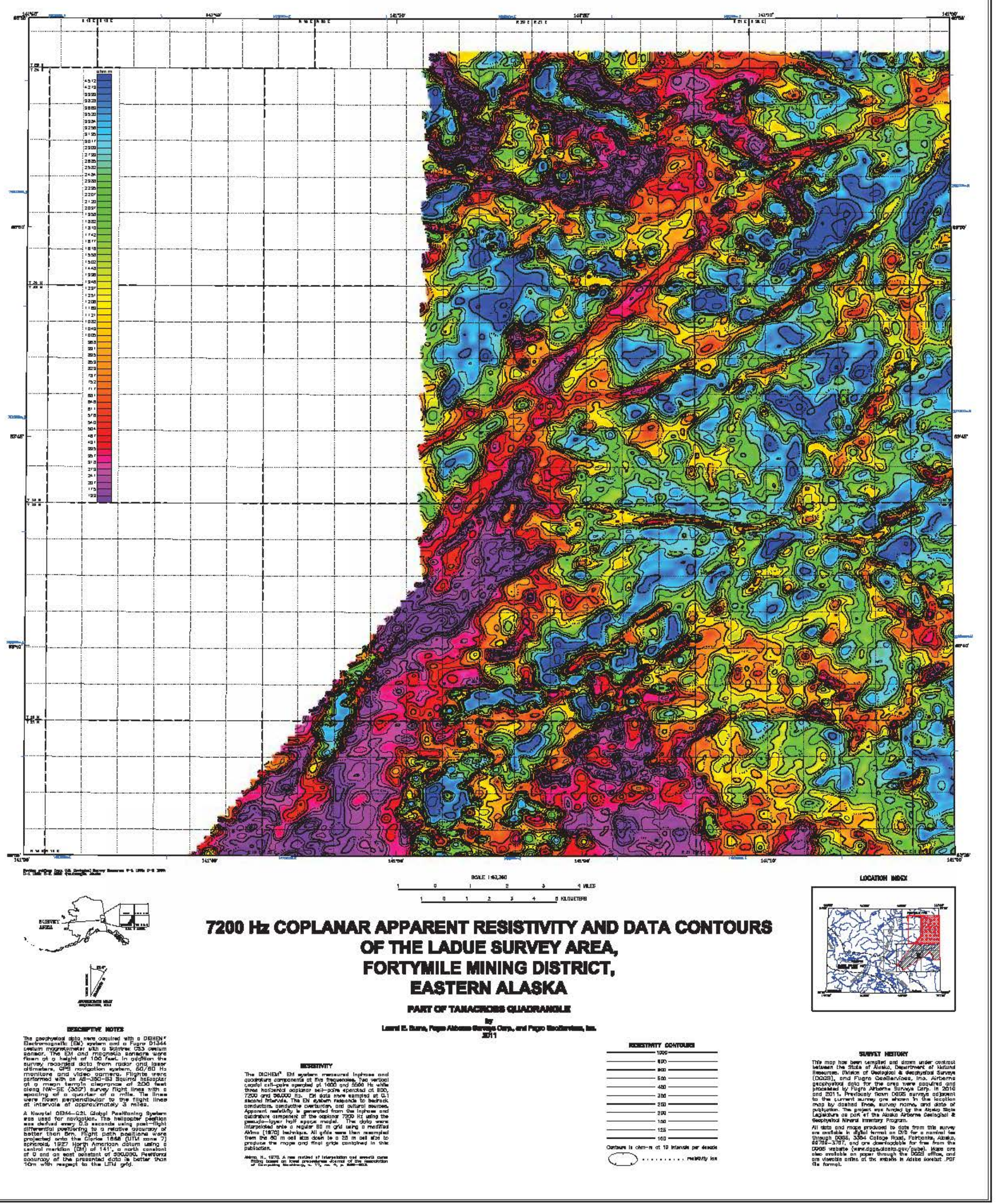




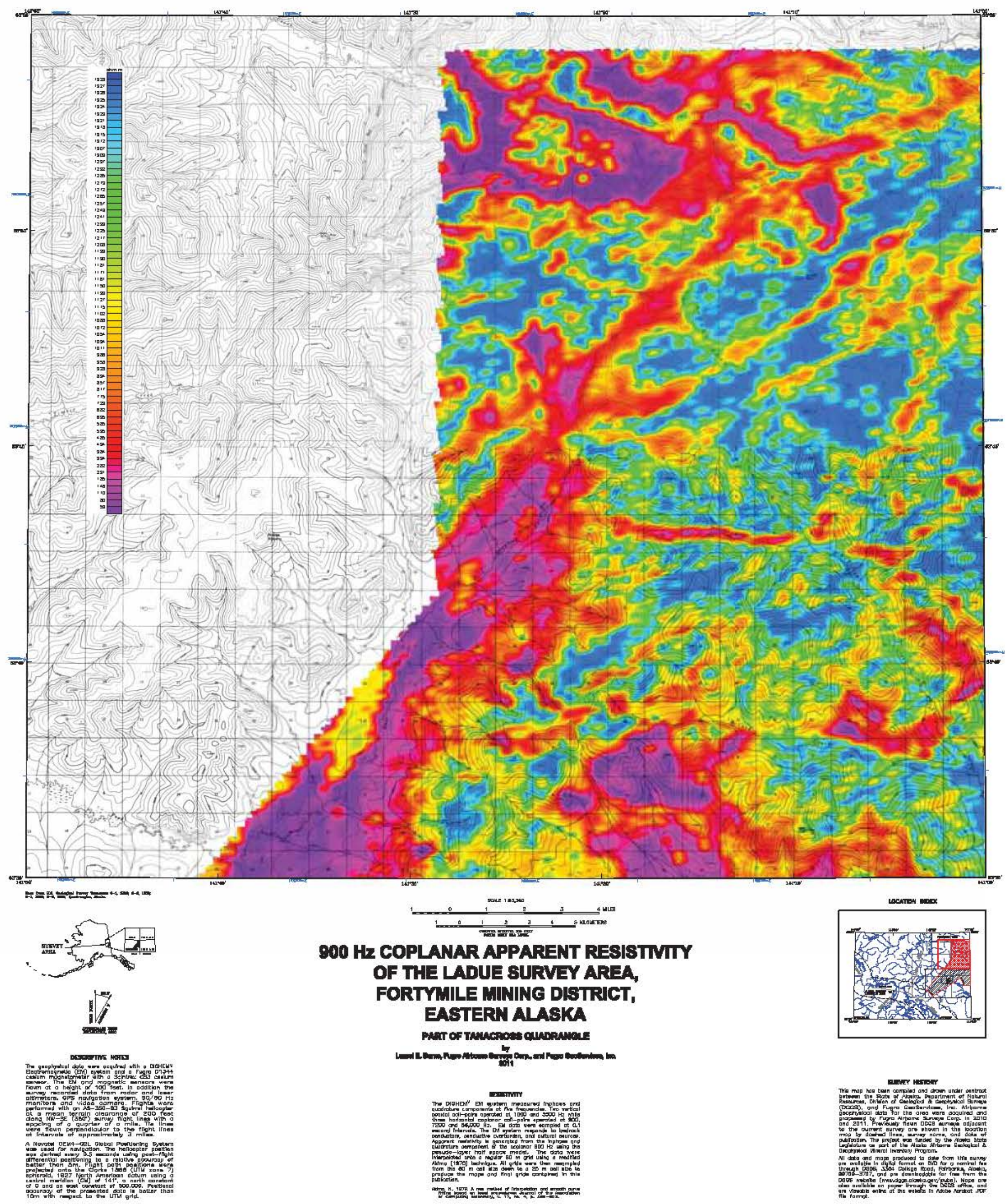




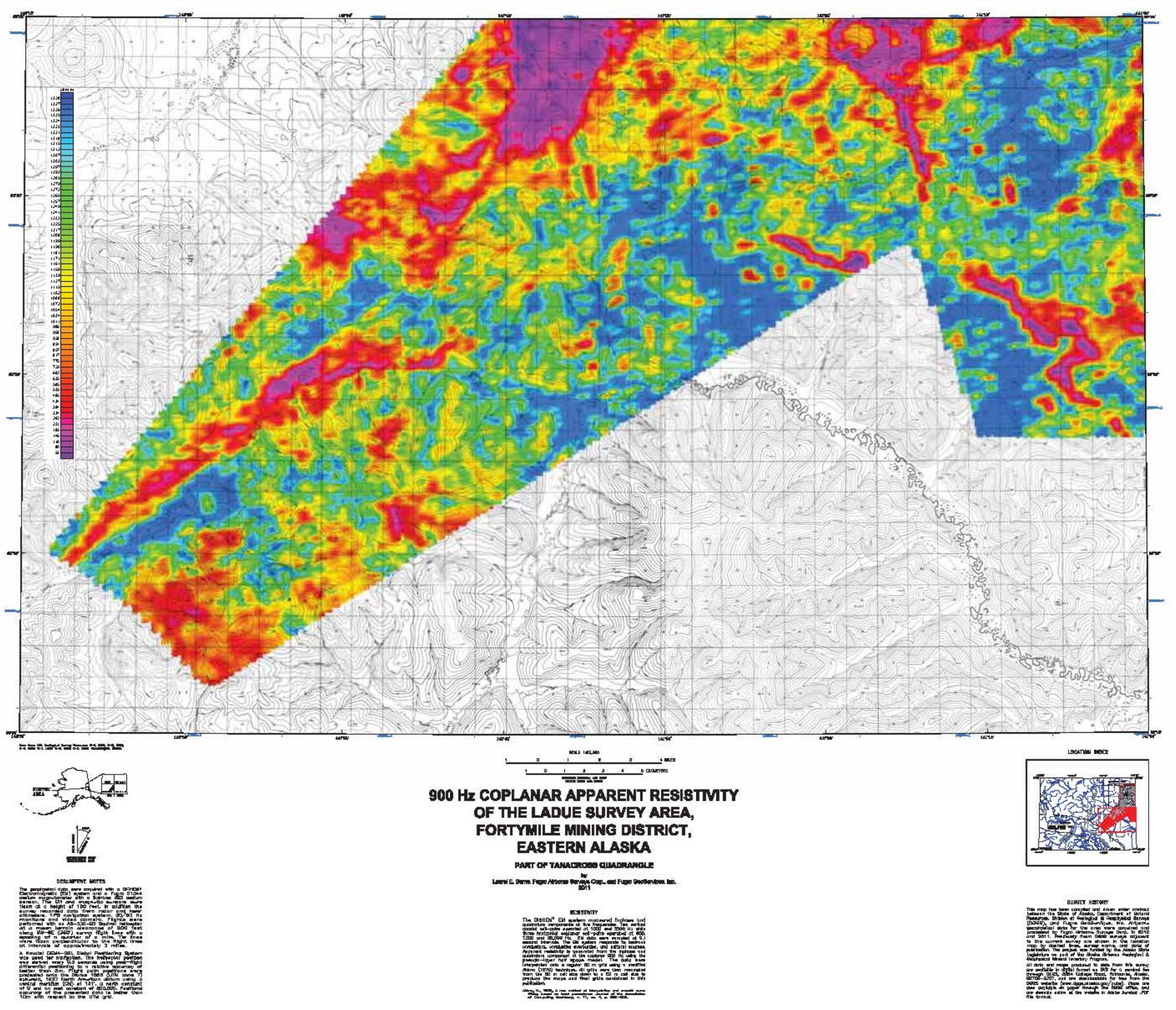




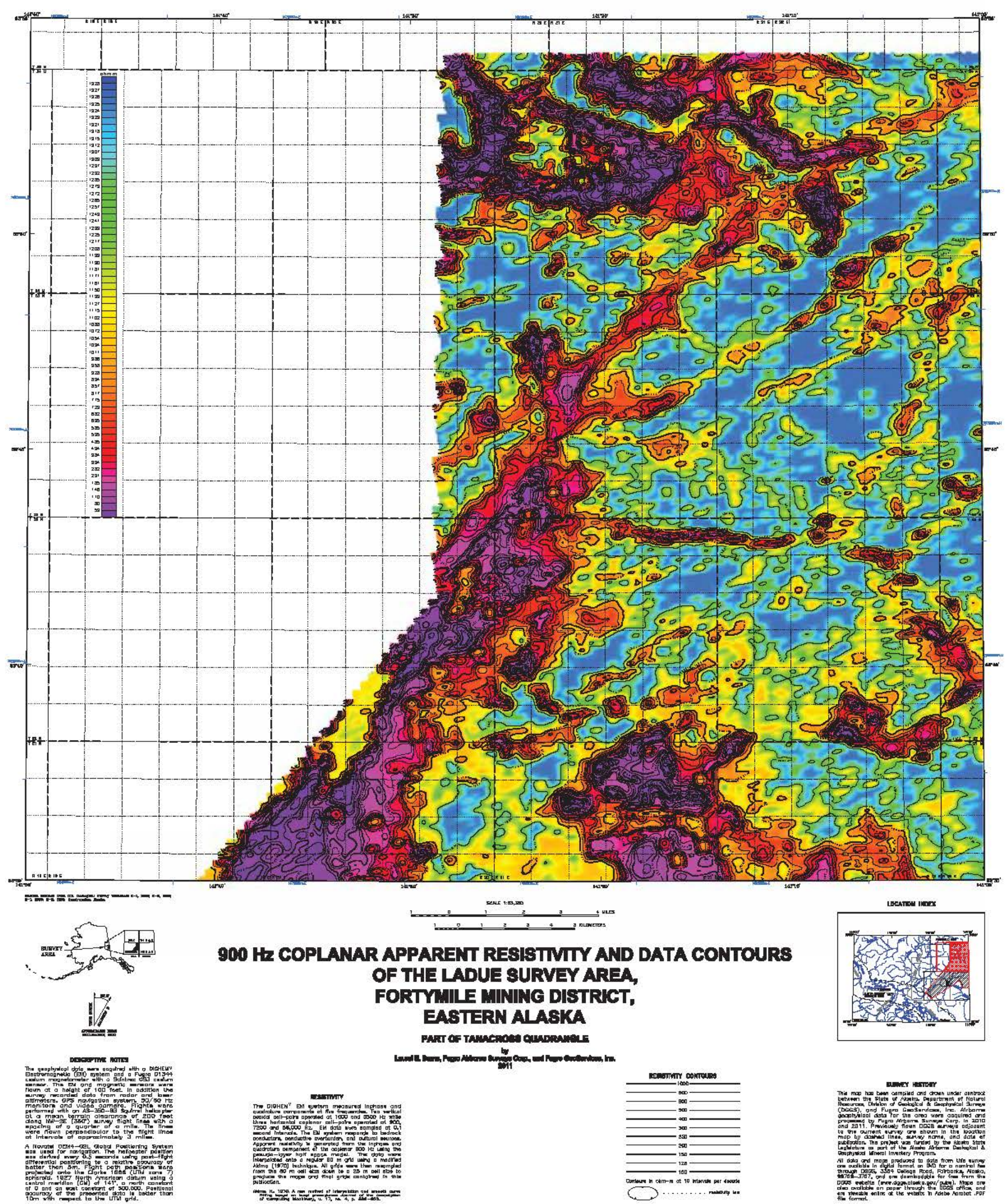




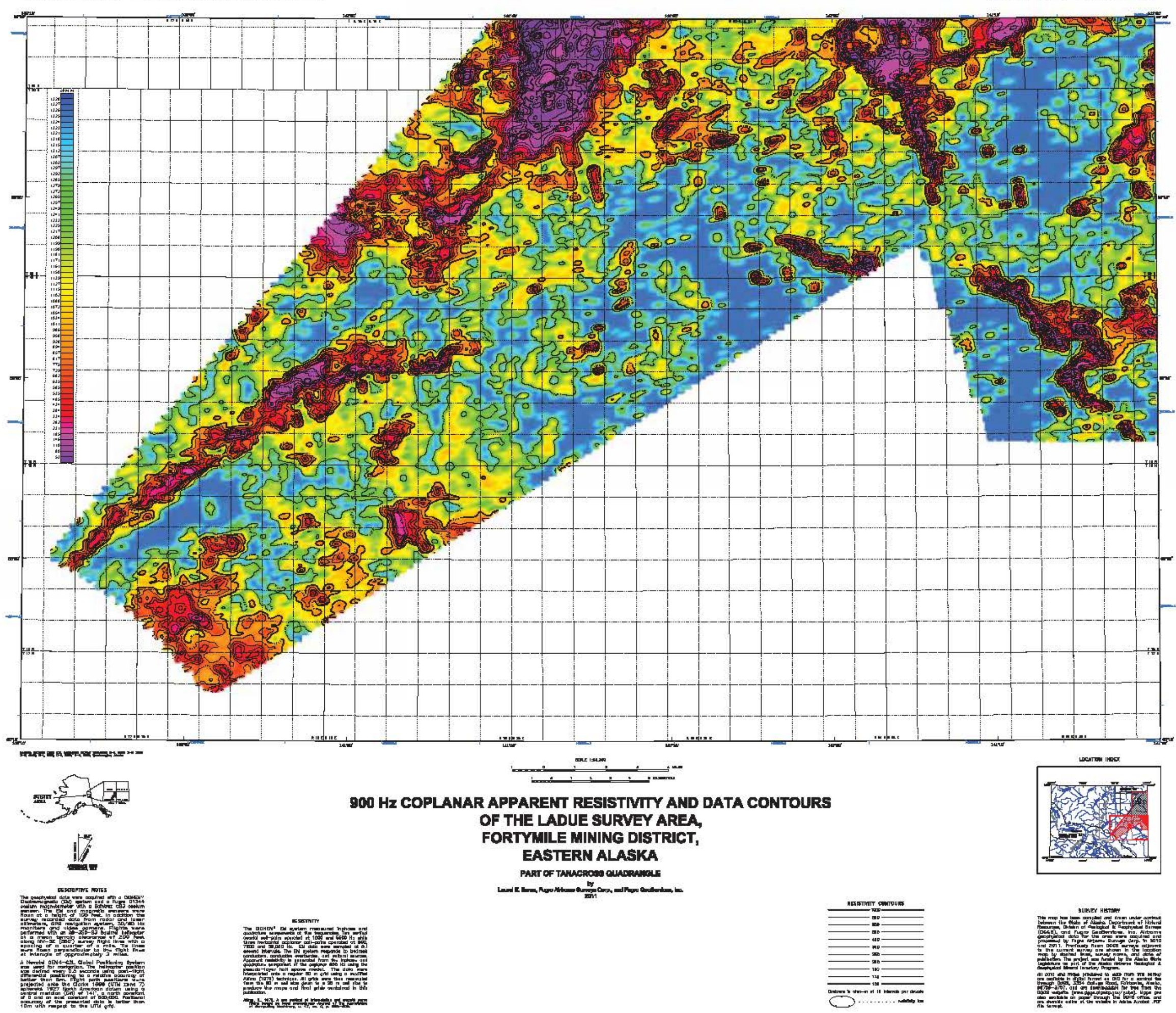




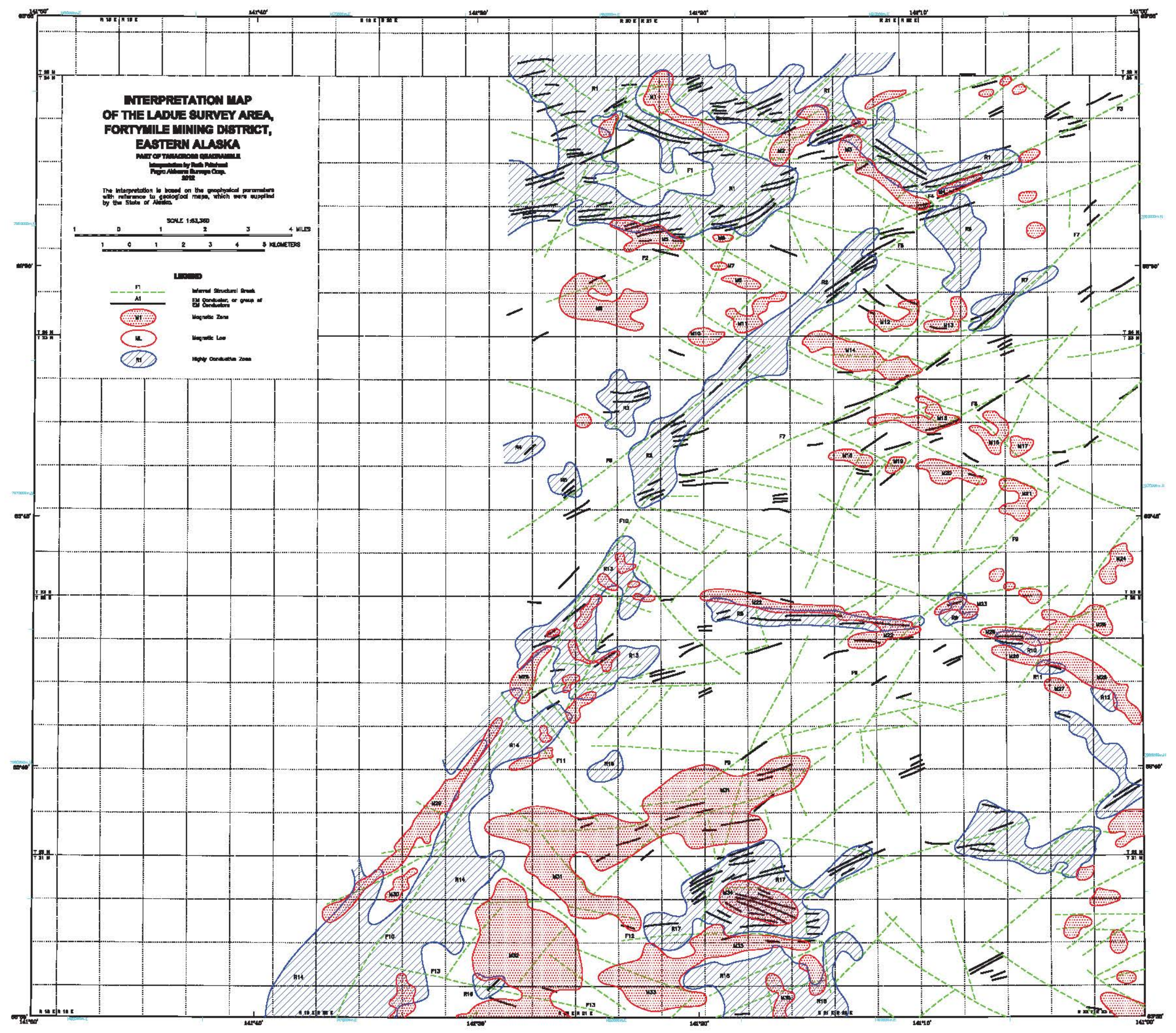




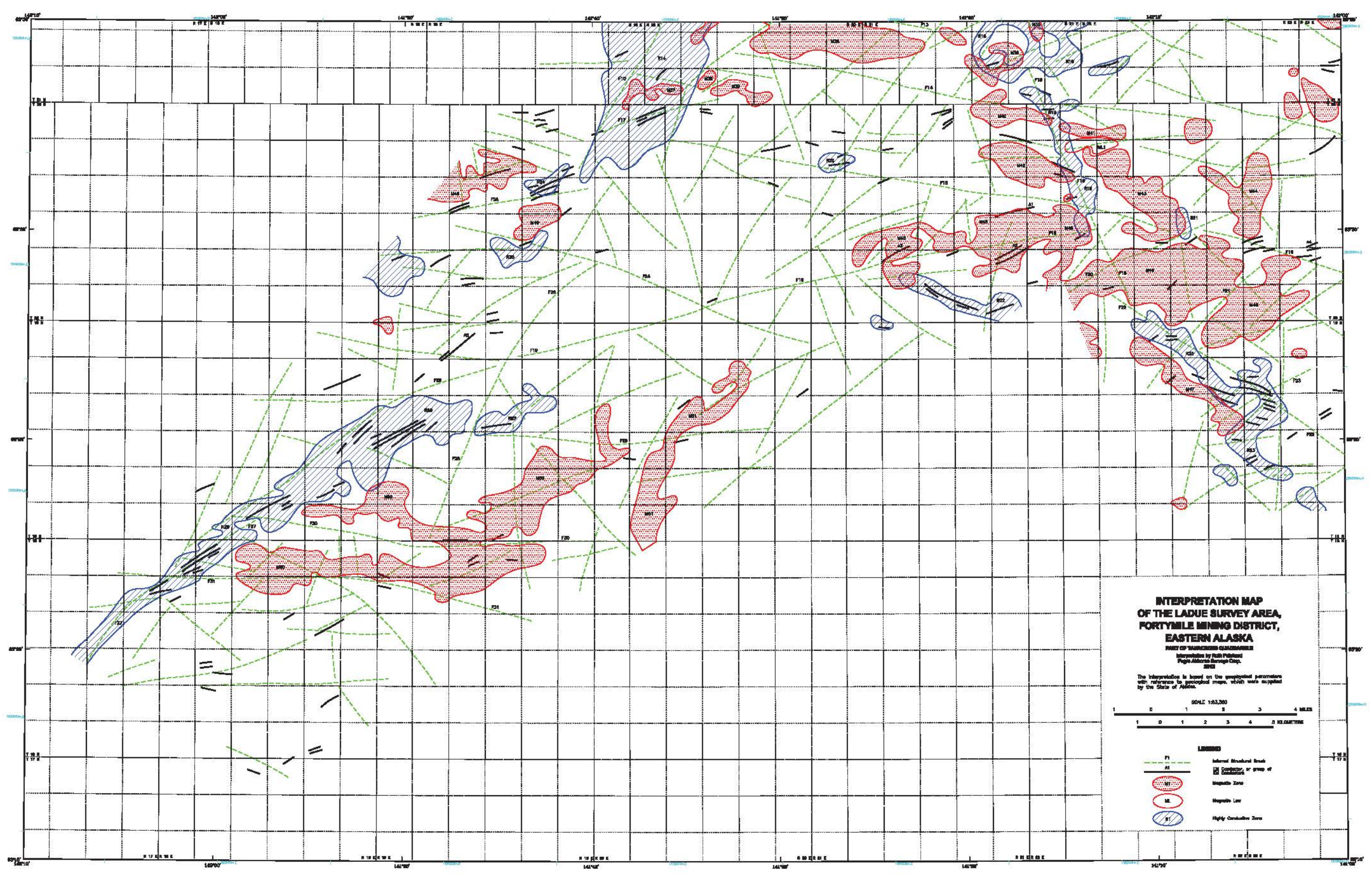


ALASKA DIMISION OF GEOLOGICAL \& GEOPHYSICAL SURVEYS

GEOPHYSICAL REPORT 2011-3-2C

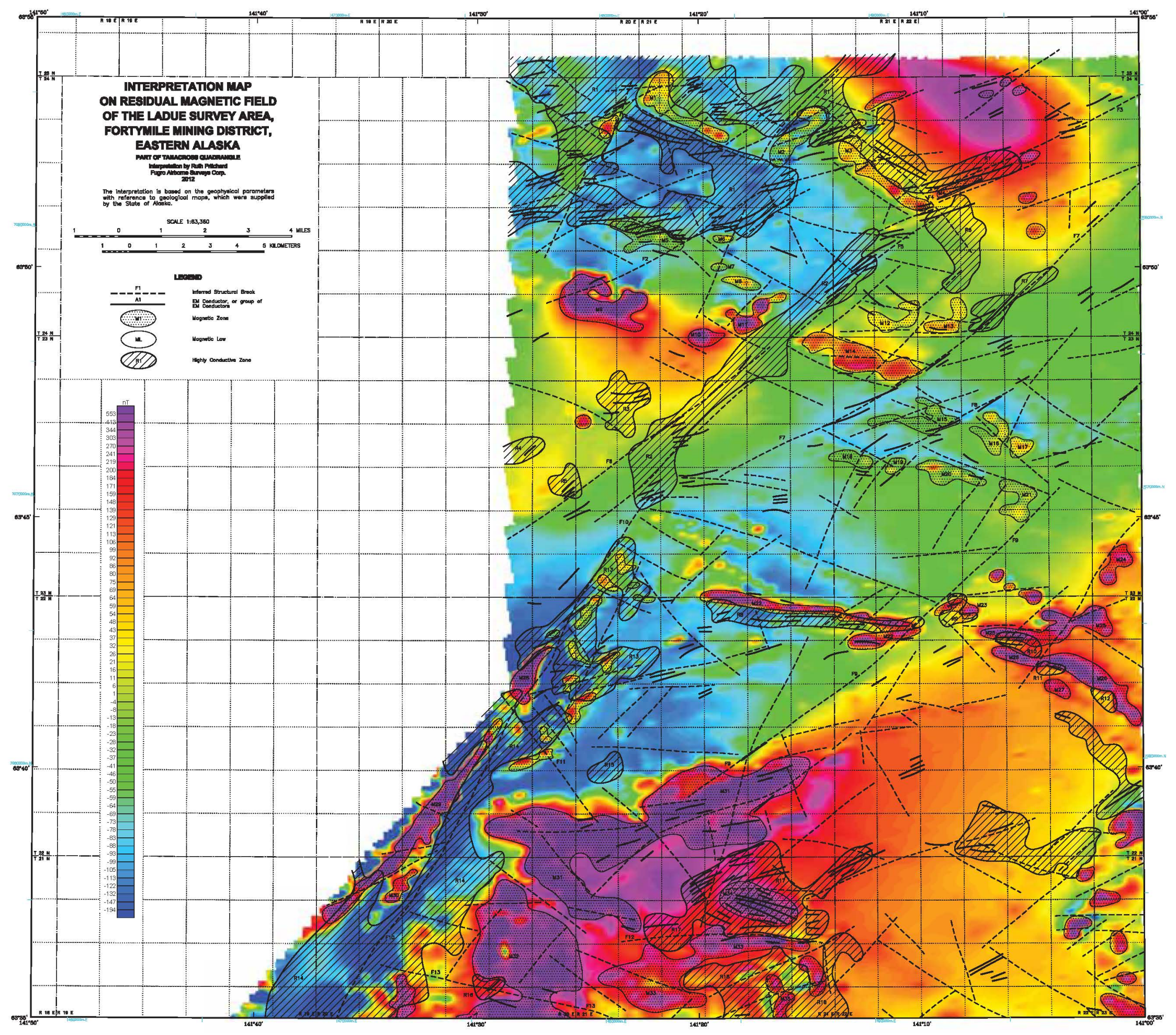




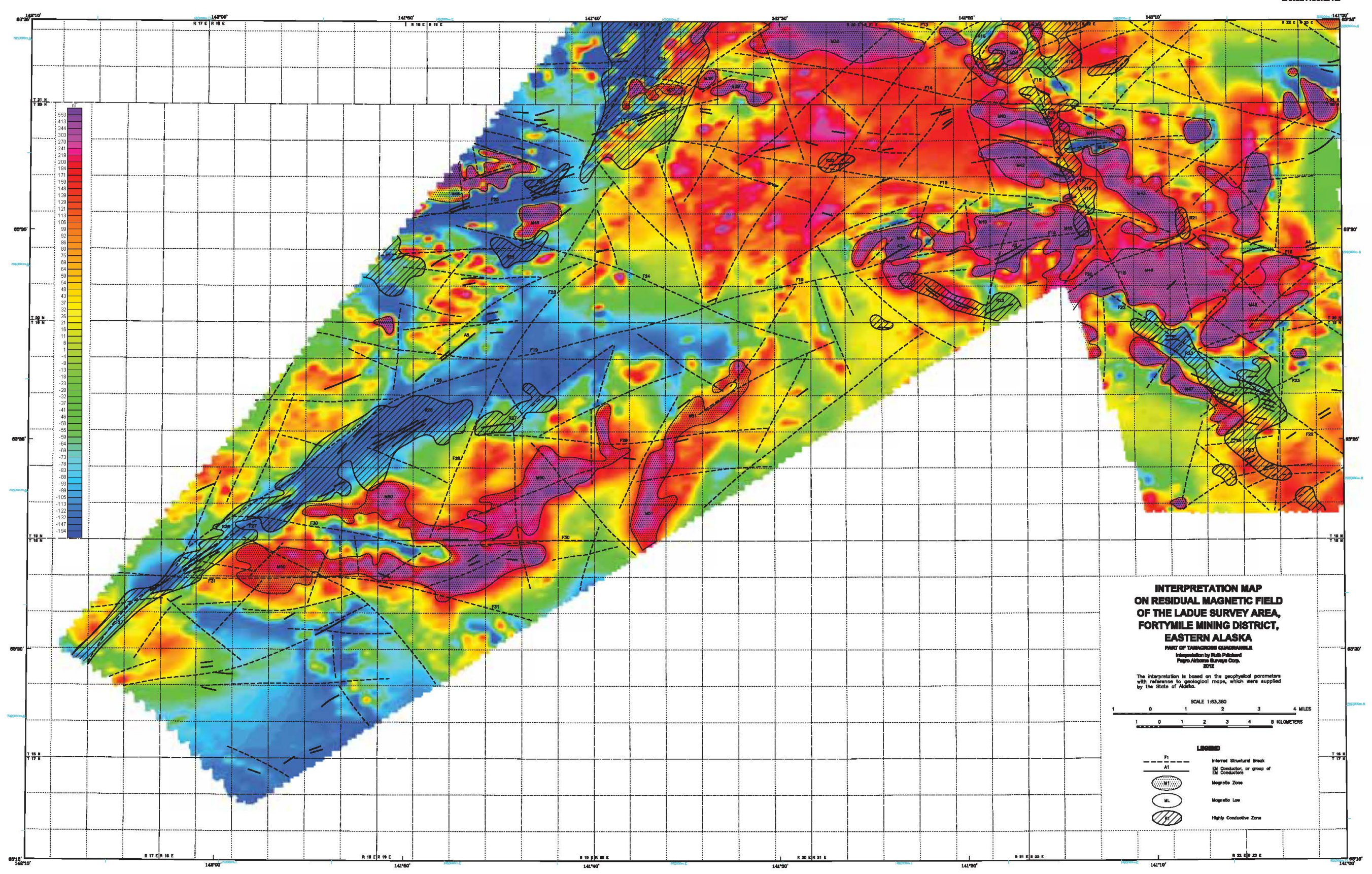




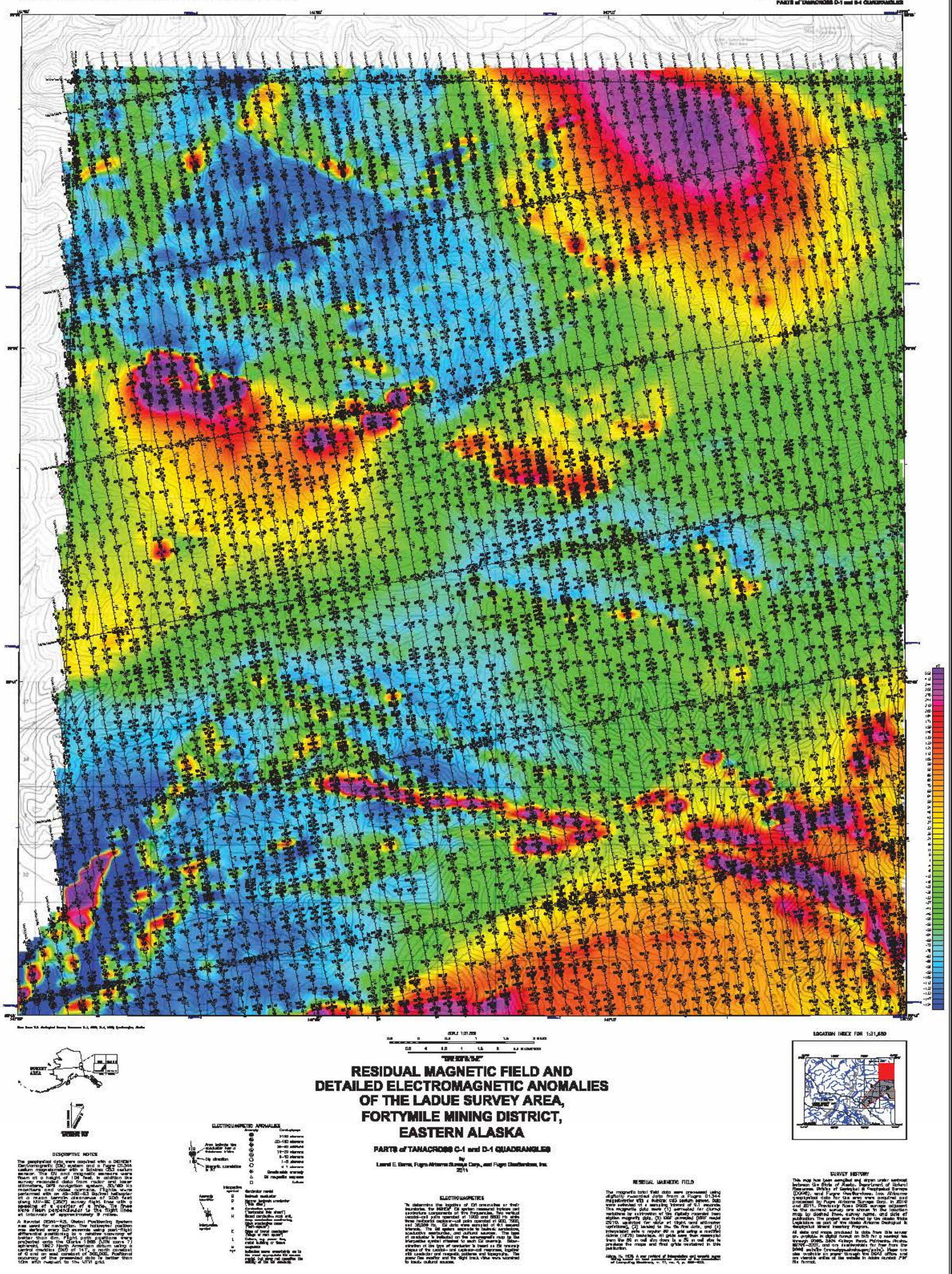




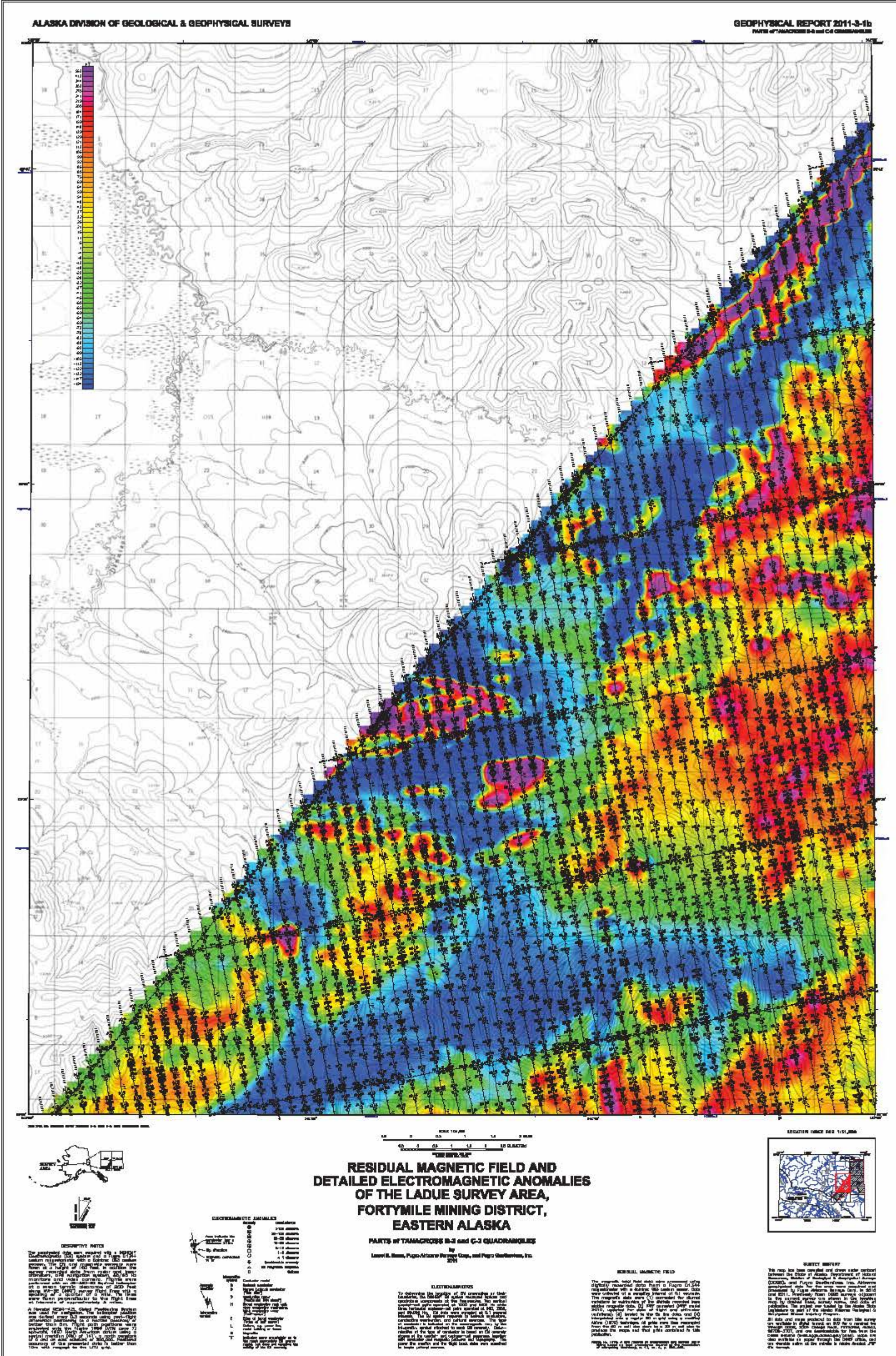




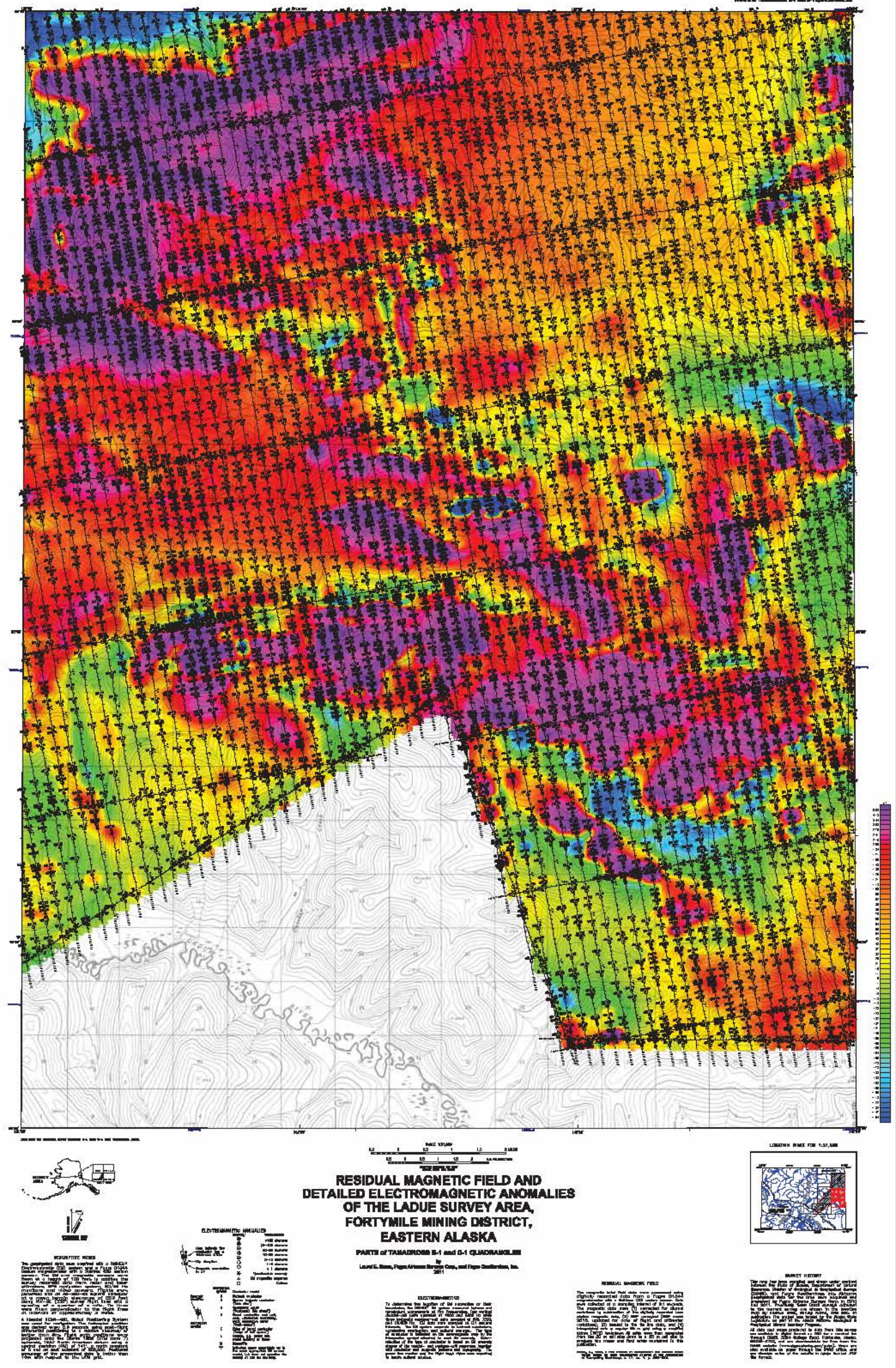




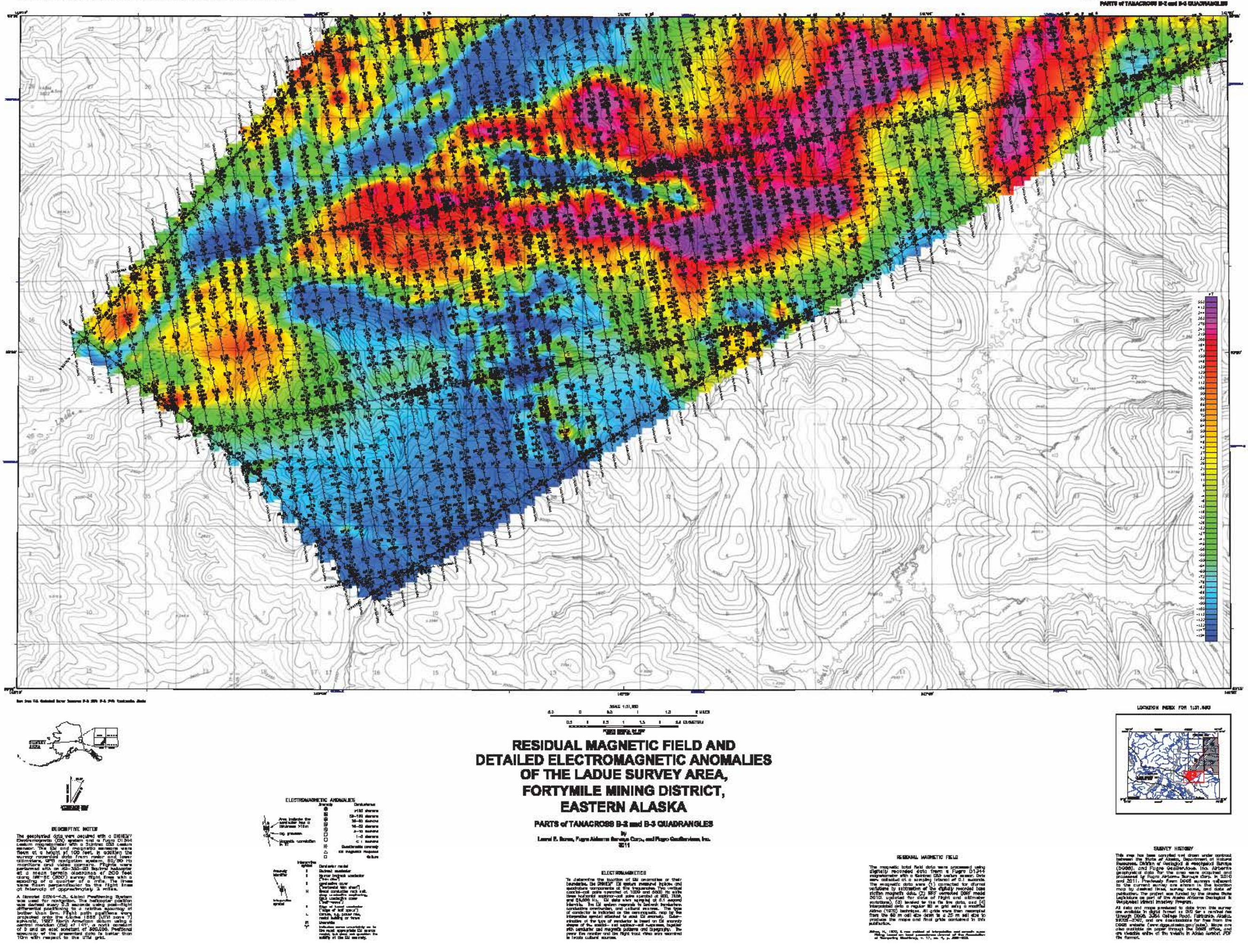

